\title{
Role of mesoscale cyclonic eddies in the distribution and activity of Archaea and Bacteria in the South China Sea
}

\author{
Yao Zhang ${ }^{1}$, Eva Sintes ${ }^{2}$, Jianing Chen ${ }^{1}$, Yong Zhang ${ }^{1}$, Minhan Dai ${ }^{1}$, Nianzhi Jiao ${ }^{1}$, \\ Gerhard J. Herndl ${ }^{2,3, *}$
}

${ }^{1}$ State Key Laboratory for Marine Environmental Sciences, Xiamen University, 422 Siming South Road, Xiamen 361005, China

${ }^{2}$ Department of Biological Oceanography, Royal Netherlands Institute for Sea Research (NIOZ), PO Box 59, 1790 AB Den Burg, The Netherlands

${ }^{3}$ University of Vienna, Ecology Center, Department of Marine Biology, Althanstr. 14, 1090 Vienna, Austria

\begin{abstract}
We examined the effect of 2 cold-core cyclonic eddies on the activity of the prokaryotic plankton community in the South China Sea. The abundance of bulk prokaryotes and major prokaryotic groups (Bacteria, marine Crenarchaeota Group I and marine Euryarchaeota Group II) and the number of cells taking up D- vs. L-aspartic acid (Asp) were determined using microautoradiography combined with catalyzed reporter deposition fluorescence in situ hybridization (MICRO-CARDFISH). At all sites, the bulk D-Asp:L-Asp uptake ratio by the prokaryotic community increased with depth. Concurrently, the contribution of marine Crenarchaeota Group I to total prokaryotic abundance and total active cells also increased with depth, while an opposite pattern was observed for Bacteria. Marine Euryarchaeota Group II were generally more dominant in near-surface than in deep waters. Significant differences were observed between sites inside and outside the cyclonic eddies in terms of distribution and activity of prokaryotic communities and the concentration of fluorescent dissolved organic matter (FDOM, an important refractory fraction of DOM). Generally, higher bulk DAsp:L-Asp uptake ratios by the prokaryotic community and a greater crenarchaeotal contribution were found in the upper mesopelagic water column inside the cold-core eddies as compared to the outside sites. Taken together, the MICRO-CARD-FISH data and the pattern of FDOM indicate that the higher contribution of refractory DOM induced by upwelled water in the cyclonic eddy may have led to a more prominent role of Crenarchaeota in the organic carbon cycling in the mesopelagic realm of the cold-core eddy than outside the eddy in the South China Sea.
\end{abstract}

KEY WORDS: Cyclonic eddy · Archaea ' Bacteria · Enantiomeric amino acid uptake . DOM fluorescence

Resale or republication not permitted without written consent of the publisher

\section{INTRODUCTION}

The presence of mesoscale cyclonic eddies can have a significant impact on regional biogeochemical processes due to the introduction of new nutrients into the photic zone that leads to elevated primary production and altered efficiency of the biological pump as compared to the surrounding waters. Previous studies on mesoscale cyclonic eddies have focused largely on their physical and nutrient dynamics and/or the response of phyto- and microzooplankton (Allen et al. 1996, Benitez-Nelson et al. 2007, McGillicuddy et al. 2007). Recently, Ewart et al. (2008) reported on the bacterial biomass and production associated with eddy-induced upwelling in the surface waters of the Sargasso Sea. However, little is known about the influence of mesoscale cyclonic eddies that lead to an upwelling of deep waters on the distribution and heterotrophic activity of Archaea vs. Bacteria in the mesopelagic water column. 
Quantitative studies using fluorescence in situ hybridization (FISH) have revealed that in the ocean's interior, planktonic Archaea (Crenarchaeota and Euryarchaeota) might account for about one-third of all prokaryotic cells in the global ocean (Karner et al. 2001), and that marine Crenarchaeota Group I are ubiquitously distributed in the deep ocean (Herndl et al. 2005, Kirchman et al. 2007, Varela et al. 2008). Also, studies have shown that, at least, some Crenarchaeota are chemoautotrophic, utilizing inorganic carbon as a carbon source (Herndl et al. 2005, Wuchter et al. 2006) and oxidizing ammonia as an energy source (Könneke et al. 2005). Other studies have reported substantial heterotrophy in Crenarchaeota as indicated by the uptake of amino acids (Ouverney \& Fuhrman 2000, Teira et al. 2006a). At present, a mechanistic understanding of the factors controlling the distribution and extent of hetero- vs. autotrophic activity of the main archaeal group, the Crenarchaeota, is still largely lacking (Agogué et al. 2008).

Among the members of the prokaryotic community, the marine Crenarchaeota Group I have been shown to be mainly responsible for the uptake of D-antiomeric aspartic acid (D-Asp) in meso- and bathypelagic waters (Varela et al. 2008). The ratio of $\mathrm{D}: \mathrm{L}$-enantiomeric amino acids in dissolved organic matter (DOM) might serve as an indicator of its bioreactivity (Pérez et al. 2003), in addition to the concentration of fluorescent dissolved organic matter (FDOM) (McKnight \& Aiken 1998, Yamashita \& Tanoue 2008). In this study, we determined the distribution of the main prokaryotic groups (Bacteria, marine Crenarchaeota Group I and marine Euryarchaeota Group II) in the western South China Sea (SCS), which is an area characterized by prominent seasonal mesoscale eddies (Hwang \& Chen 2000, Wang et al. 2003). In addition, D- vs. L-aspartic acid uptake rates were determined to test for differences in DOM availability within and outside the eddies, as proposed by Pérez et al. (2003) and Teira et al. (2006b) who showed that high D-Asp:L-Asp uptake ratios are indicative of a prokaryotic community that is adapted to utilize old, more refractory DOM. By comparing the distribution of the main prokaryotic groups, their uptake of Dvs. L-Asp and the vertical profiles of FDOM inside and outside the cyclonic eddy systems, we found that the meso- scale cold-core eddies modified the commonly observed vertical profile of prokaryotic community composition and activity in the mesopelagic water column of the SCS.

\section{MATERIALS AND METHODS}

Sampling area. The SCS with its deep basin, is one of the largest marginal seas in the tropical Pacific ( $\mathrm{Hu}$ et al. 2000). Its basin-scale circulation is dominated by both the East Asian monsoon and the Kuroshio, which is the subtropical western boundary current of the North Pacific. Mesoscale eddies are a prominent feature of the SCS. Four to 6 mesoscale eddies are present at any given time over the deep basin of the SCS (Hwang \& Chen 2000, Wang et al. 2003). Driven by the prevailing southwesterly monsoonal winds in summer, cold-core cyclonic eddies are formed in the western SCS (Hu et al. 2000).

High-resolution surveys (Fig. 1B) were carried out to localize eddies during the GOE-2 cruise on board the RV 'Dongfanghong' \#2 on 14 Aug to 14 Sept 2007. For

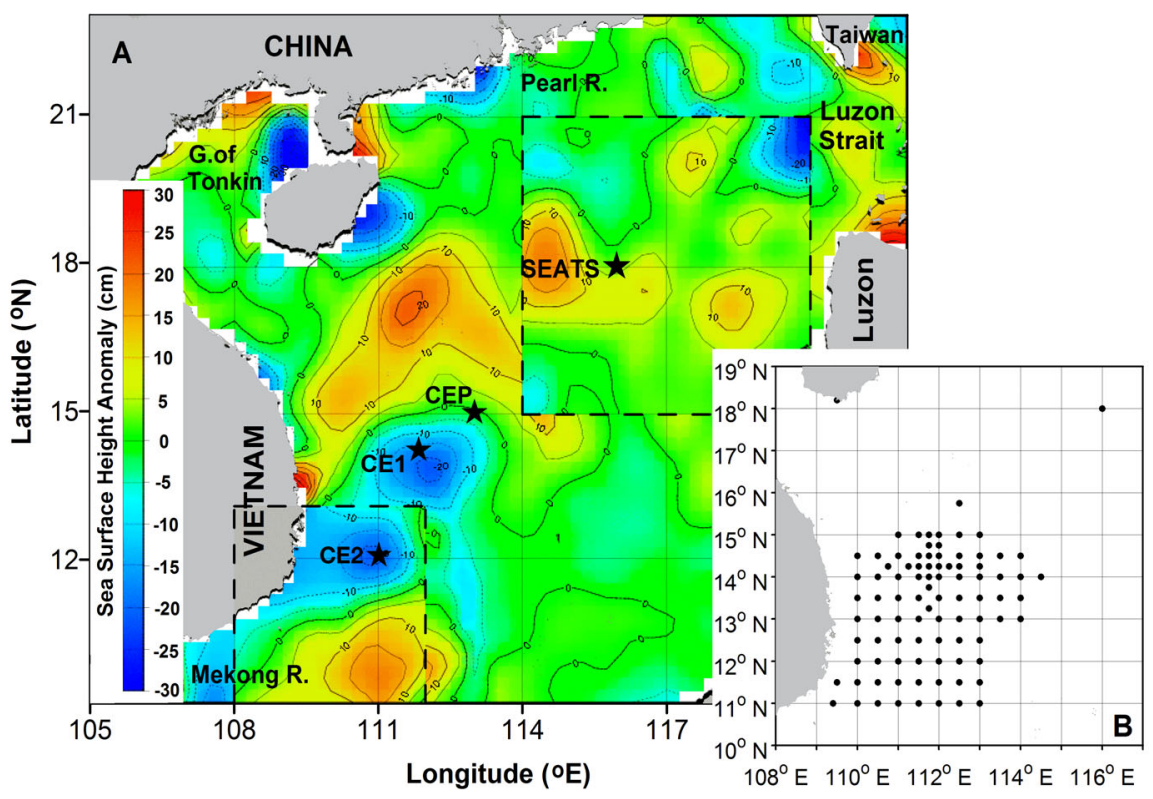

Fig. 1. (A) Map of the South China Sea showing the stations ( $\star$ ) sampled for microautoradiography and catalyzed reporter deposition fluorescence in situ hybridization (CARD-FISH) (CE1 at $111.83^{\circ} \mathrm{E}, 14.25^{\circ} \mathrm{N}$; CE2 at $111.03^{\circ} \mathrm{E}, 12.03^{\circ} \mathrm{N}$; $\mathrm{CEP}$ at $113.00^{\circ} \mathrm{E}, 15.00^{\circ} \mathrm{N}$; and SEATS at $115.96^{\circ} \mathrm{E}, 18.03^{\circ} \mathrm{N}$ ). The water depths at these 4 sites are 2844,2418, 2778 and $3839 \mathrm{~m}$, respectively. The background is a mosaic base map of real-time mesoscale sea-surface height altimetry remote sensed image with contours (http://argo.colorado.edu/ realtime/gsfc_globalreal-time_ssh/) for 26 August 2007 (date sample from CE1 was taken) (the whole image), 5 September 2007 (date sample from CE2 was taken) (108 to $112^{\circ} \mathrm{E}, 9$ to $13^{\circ} \mathrm{N}$ ) and 13 September 2007 (date sample from SEATS1 was taken) (114 to $120^{\circ} \mathrm{E}, 15$ to $21^{\circ} \mathrm{N}$ ). - - -: Boundaries of different images; CE1: cold-core cyclonic eddy \#1; CE2: cold-core cyclonic eddy \#2; CEP: cold-core cyclonic eddy periphery; SEATS: a time-series station in the South China Sea. (B) All survey sites during the cruise $(\bullet)$ 
this study, 4 stations were established. At each station, a vertical profile with 8 depths from the surface to meso- and bathypelagic waters was sampled. Two stations were located inside cold-core cyclonic eddies (CE1 and CE2), one station was at the cold-core eddy periphery (CEP), and another was at the Southeast Asia Time-Series Study station (SEATS) (Fig. 1A).

Hydrographic parameters. A CTD-General Oceanic rosette sampler with Go-Flo bottles (SBE 9/17 plus, SeaBird) was used to record temperature and salinity, and to collect water samples. Samples for inorganic nutrients (nitrate + nitrite, phosphate, silicate) were filtered through $0.45 \mu \mathrm{m}$ cellulose acetate filters and measured immediately onboard using a flow injection analyzer (Tri-223 autoanalyzer) and standard spectrophotometric methods (Pai et al. 1990). Oxygen concentrations were determined onboard using the Winkler method (Carpenter 1965). Apparent oxygen utilization (AOU) and oxygen saturation $\left(\mathrm{O}_{2}{ }^{\mathrm{S}}\right)$ were estimated based on in situ $\mathrm{O}_{2}$, temperature and salinity (Garcia et al. 2006). Samples for chl a analysis were collected on $0.7 \mu \mathrm{m}$ pore-size GF/F filters (Whatman) and chl a was determined using a fluorometer (Turner Designs, Model 10). Chl a data were provided by the GOE (Group of Excellent) project (B.Q. Huang, Xiamen University, China).

To assess the evolution of the cold eddies, the sea surface height anomaly was monitored through realtime mesoscale altimetry using images acquired from the Colorado Center for Astrodynamics Research (CCAR, USA).

Picoplankton production determined by ${ }^{3} \mathrm{H}$-leucine incorporation. To determine heterotrophic picoplankton production, triplicate $10 \mathrm{ml}$ samples were incubated with $\left[{ }^{3} \mathrm{H}\right]$ leucine (10 $\mathrm{nM}$ final concentration; 65 $\mathrm{Ci} \mathrm{mmol}^{-1}$, Amersham) in the dark at in situ temperature for $4 \mathrm{~h}$ (Herndl et al. 2005). Triplicate killed controls were fixed with $2 \%$ paraformaldehyde (Sigma) prior to $\left[{ }^{3} \mathrm{H}\right]$ leucine addition. Incubations were terminated by adding $2 \%$ paraformaldehyde. The fixed samples were filtered $(<0.3 \mathrm{~atm})$ onto $0.2 \mu \mathrm{m}$ pore size, white polycarbonate filters supported by $0.45 \mu \mathrm{m}$ nitrocellulose filters (Whatman), then rinsed $3 \times$ with $10 \mathrm{ml}$ of $5 \%$ ice-cold trichloroacetic acid, dried and placed in scintillation vials. Samples were stored at $-20^{\circ} \mathrm{C}$ until analysis in the laboratory. Filters were dissolved in $1 \mathrm{ml}$ of ethyl acetate (Sigma) for $10 \mathrm{~min}, 8 \mathrm{ml}$ of scintillation cocktail (UltimaGold) was added, and counting in a liquid scintillation counter (1220 QuantulusTM, Wallac) was done after $12 \mathrm{~h}$. The disintegrations per minute (DPM) of the paraformaldehyde-fixed blanks were subtracted from the mean DPM of the respective samples, and the resulting DPM converted into leucine incorporation rates. The analytical error of the estimates was $<10 \%$.
Uptake of D-Asp and L-Asp by the bulk prokaryotic community. Triplicate $40 \mathrm{ml}$ samples were incubated with D-[2,3- $\left.{ }^{3} \mathrm{H}\right]-$ Asp (1 nM final concentration; $36 \mathrm{Ci}$ $\mathrm{mmol}^{-1}$, Amersham) and L-[2,3- $\left.{ }^{3} \mathrm{H}\right]$-Asp (1 nM final concentration; $37 \mathrm{Ci} \mathrm{mmol}^{-1}$, Amersham) in the dark at in situ temperature for $8 \mathrm{~h}$ (Teira et al. 2006a). Triplicate killed controls were fixed with $2 \%$ paraformaldehyde (Sigma) prior to substrate addition. Incubations were also terminated with $2 \%$ paraformaldehyde. Fixed samples were filtered as described above, rinsed twice with $0.2 \mu \mathrm{m}$ filtered seawater and stored in scintillation vials at $-20^{\circ} \mathrm{C}$ until analysis. Radioactivity was determined as described above for leucine incorporation, and the DPM converted to D- and L-Asp uptake rates. The analytical error of the estimates was $<10 \%$.

Abundance of Archaea and Bacteria determined by CARD-FISH. Samples of $40 \mathrm{ml}$ were immediately fixed with freshly prepared paraformaldehyde $(2 \%$ final concentration) and stored at $4{ }^{\circ} \mathrm{C}$ overnight prior to filtration onto $0.2 \mu \mathrm{m}$ pore size polycarbonate filters (Whatman). Filtered samples were stored at $-20^{\circ} \mathrm{C}$ for later analysis by CARD-FISH. Picoplankton abundance was determined by DAPI staining, and Archaea and Bacteria were enumerated by CARD-FISH. Filters were embedded in low-gelling-point agarose and incubated either with lysozyme for the Bacteria probe mix (Eub338: 5'-GCT GCC TCC CGT AGG AGT-3', Eub338II: 5'-GCA GCC ACC CGT AGG TGT3' and Eub338III: 5'-GCT GCC ACC CGT AGG TGT $3^{\prime}$ ) and for the negative control probe (Non338: 5'-ACT CCT ACG GGA GGC AGC-3') or with proteinase-K for the marine Crenarchaeota Group I probe mix (Cren537: 5'-TGA CCA CTT GAG GTG CTG-3' and Cren554: 5'-TTA GGC CCA ATA ATC MTC CT-3') and for the marine Euryarchaeota Group II probe (Eury806: 5'-CAC AGC GTT TAC ACC TAG-3') (DeCorte et al. 2009). Filters were cut into 8 pieces and hybridized with horseradish peroxidase (HRP)-labeled oligonucleotide probes and tyramide Alexa488 for signal amplification following the protocol described by Teira et al. (2004).

Enumeration of D-Asp and L-Asp active archaeal and bacterial cells by MICRO-CARD-FISH. Microautoradiography was applied on samples collected at stations CE1 and CEP. Triplicate samples of $40 \mathrm{ml}$ were incubated with D-[2,3-3H]-Asp (10 nM final concentration; $36 \mathrm{Ci} \mathrm{mmol}^{-1}$, Amersham) and L-[2,3-3H]-Asp (10 nM final concentration; $37 \mathrm{Ci} \mathrm{mmol}^{-1}$, Amersham) in the dark at in situ temperature for $8 \mathrm{~h}$ (Teira et al. 2006a). Killed controls were fixed with $2 \%$ paraformaldehyde (Sigma) prior to substrate addition. Incubations were terminated with $2 \%$ paraformaldehyde and stored in the dark at $4{ }^{\circ} \mathrm{C}$ for $12 \mathrm{~h}$. Thereafter, samples were filtered $(<0.3 \mathrm{~atm})$ onto $0.2 \mu \mathrm{m}$ pore size, white polycarbonate membrane filters supported by 
$0.45 \mu \mathrm{m}$ nitrocellulose membranes (Whatman), rinsed twice with Milli-Q water and stored at $-20^{\circ} \mathrm{C}$ until analysis. After the CARD-FISH procedure, hybridized filter sections were prepared for microautoradiography (Teira et al. 2004). A glass slide was dipped into a molten $\left(43^{\circ} \mathrm{C}\right)$ solution of NTB-2 emulsion (Kodak) diluted to 2 parts of emulsion and 1 part of Milli-Q water. The filters with the cells were placed in contact with the molten emulsion. The glass slides were then placed on an ice-cold aluminum block for $10 \mathrm{~min}$ to solidify the emulsion before being transferred to lighttight boxes containing a drying agent for autoradiographic exposure at $4^{\circ} \mathrm{C}$ for $7 \mathrm{~d}$. The emulsion was developed following Kodak's specifications. Before complete drying, filter sections were removed and cells were counterstained with a DAPI mix: 5.5 parts of Citifluor (Citifluor), 1 part of Vectashield (Vector Laboratories) and 0.5 parts of phosphate-buffered saline (PBS) with DAPI (final concentration of $5 \mu \mathrm{g} \mathrm{ml}^{-1}$ ).

Microscopy and image analysis. The slides were assayed by microscopy using images acquired by fluorescence and transmitted light, and a digital camera (AxioCam MRc5) mounted on an epifluorescence microscope (Zeiss Axioplan 2) equipped with a $100 \mathrm{~W}$ mercury lamp and a tungsten lamp. Cells in 10 to 30 microscopic fields were examined per sample. Three images were acquired for each field. DAPI and Alexa488 images were acquired using appropriate filter sets with optimized manual exposure time of 400 to $1900 \mathrm{~ms}$. Negative control counts (hybridization with HRP-Non338) were always $<1 \%$ of DAPI-stained cells. Images of silver grains were obtained using transmitted light with automatic exposure. In the killed controls, $<0.5 \%$ of the total DAPI-stained cells were associated with silver grain halos. More than 500 DAPI- stained cells were counted per sample. The 3 images were overlaid to obtain composite images to identify DAPI-stained cells, probe-positive cells and cells with silver grains. For each microscopic field, 4 categories were differentiated: (1) total DAPI-stained cells, (2) cells stained with a specific probe, (3) DAPI-stained cells with associated silver grain halos, and (4) cells labeled with a specific fluorescent probe and silver grain halos associated with individual cells. The analytical error of the estimates was $<10 \%$.

Measurement of FDOM. The FDOM was measured as a proxy for biorefractory DOM in subsurface waters (Yamashita \& Tanoue 2008). Seawater was filtered through pre-cleaned $0.22 \mu \mathrm{m}$ pore size polycarbonate membrane filters (Millipore). Fluorescence was measured onboard using the Turner Designs (Model 10AU) fluorometer equipped with an FDOM optical kit at 310 to $390 \mathrm{~nm}$ excitation and 400 to $600 \mathrm{~nm}$ emission. The fluorescence of the samples is expressed in qui- nine sulfate units (QSU) where $1 \mathrm{QSU}$ is equivalent to the fluorescence of $1 \mu \mathrm{g} \mathrm{l}^{-1}$ quinine sulfate solution. For comparison, series of duplicate samples were also measured in a $1 \times 1 \mathrm{~cm}$ quartz cell with a spectrofluorometer (Cary Eclipse, Varian) at $350 \mathrm{~nm}$ excitation and $450 \mathrm{~nm}$ emission using $20 \mathrm{~nm}$ bandwidths (Ferrari \& Dowell 1998). Results obtained with the 2 instruments were not significantly different $(y=0.9207 x+$ $\left.0.1066, \mathrm{r}^{2}=0.966 ; \mathrm{p}<0.01\right)$.

Statistical analysis. Since normality of distribution of the individual data sets was not always met, we used the non-parametric Wilcoxon and Friedman tests for comparing 2 and $>2$ related variables, respectively. Model II Reduced Major Axis (RMA) regression, exponential growth and decay models (Sigmaplot) were used to determine the relationships between variables.

\section{RESULTS}

\section{Hydrographic characteristics}

Two well-developed cold-core cyclonic eddies (CE1 and CE2) were identified and their development was tracked via satellite altimetry (Fig. 1). Shipboard Acoustic Doppler Current Profiler (ADCP) data documented the counterclockwise currents in CE1 and CE2, which are associated with their negative sealevel anomaly. Their altimetric history suggested intensification of CE1 between 14 and 30 Aug, and of CE2 between 26 Aug and 12 Sept. Observations were conducted during the intensification phases as samples were taken at CE1 on 26 Aug, at CEP on 28 Aug, at CE2 on 5 Sept and at SEATS on 13 Sept (Fig. 1A).

The cores of CE1 and CE2 were located at $\sim 112.5^{\circ} \mathrm{E}, 13.5^{\circ} \mathrm{N}$ and $111^{\circ} \mathrm{E}, 12^{\circ} \mathrm{N}$, respectively. A comparison of the vertical profiles of physical and chemical parameters in the 4 stations show that the shallow waters (upper $200 \mathrm{~m}$ ) of CE1 and CE2 exhibited lower temperature, higher salinity, higher nutrient concentrations (M. Dai et al. unpubl.), lower dissolved oxygen, and higher chl a concentration (Fig. 2) and primary production (data not shown) than Stns CEP and SEATS. CEP was located at the cold-core eddy periphery and hence, was potentially influenced by the mesoscale features. SEATS was located far outside the 2 eddy systems (Fig. 1). The hydrographic data from SEATS presented here (Fig. 2) are within the range of historical data (www.ncor.ntu.edu.tw/ SEATS/SEATS_Eng.htm), indicating that SEATS is a representative outside-the-eddy station. The surface waters of CE2 were influenced by the Mekong River plume and had relatively low salinity. At all 4 sites, oxygen minimum layers were detectable at $\sim 800 \mathrm{~m}$ depth. 
CE1

Oxygen $\left(\mu \mathrm{mol} \mathrm{kg}{ }^{-1}\right)$

50100150200250

Temperature $\left({ }^{\circ} \mathrm{C}\right)$

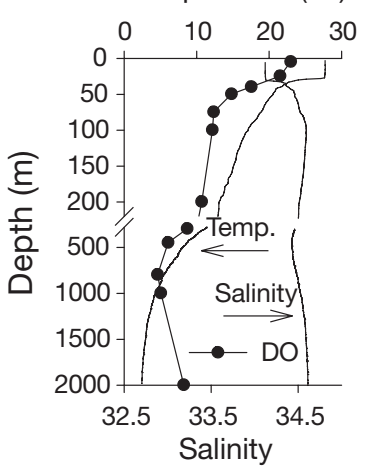

Silicate $\left(\mu \mathrm{mol} \mathrm{I}{ }^{-1}\right)$

$\begin{array}{llll}0 & 10 & 20 & 30\end{array}$

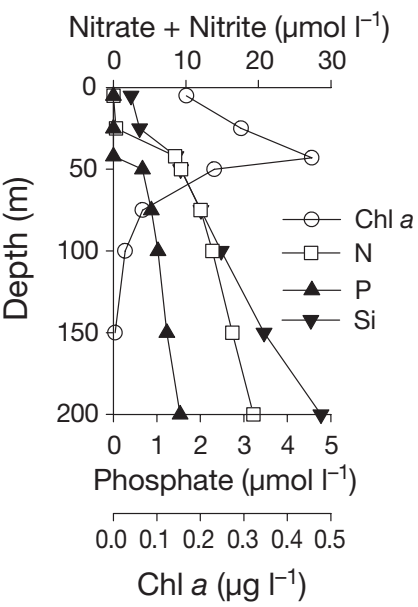

CE2

Oxygen $\left(\mu \mathrm{mol} \mathrm{kg}{ }^{-1}\right)$

50100150200250

Temperature $\left({ }^{\circ} \mathrm{C}\right)$

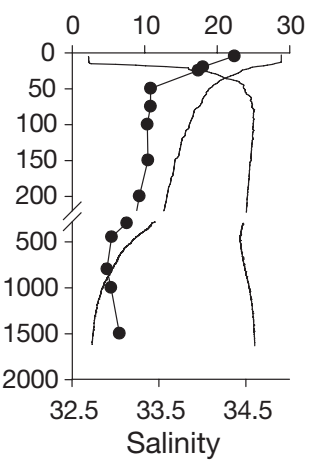

Silicate $\left(\mu \mathrm{mol} \mathrm{I}{ }^{-1}\right)$

$0 \quad 10 \quad 20 \quad 30$

Nitrate + Nitrite $\left(\mu \mathrm{mol} \mathrm{I}{ }^{-1}\right)$

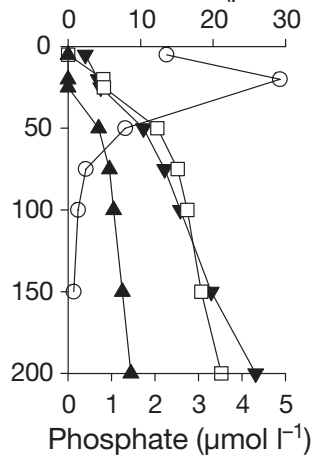

$\begin{array}{llllll}0.0 & 0.1 & 0.2 & 0.3 & 0.4 & 0.5\end{array}$

Chl a $\left(\mu \mathrm{g} \mathrm{I}^{-1}\right)$
CEP

Oxygen $\left(\mu \mathrm{mol} \mathrm{kg}{ }^{-1}\right)$

50100150200250

Temperature $\left({ }^{\circ} \mathrm{C}\right)$

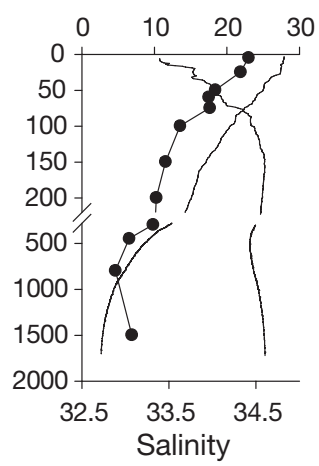

Silicate $\left(\mu \mathrm{mol} \mathrm{I}{ }^{-1}\right)$

$\begin{array}{llll}0 & 10 & 20 & 30\end{array}$

Nitrate + Nitrite $(\mu \mathrm{mol} \mathrm{I-1})$

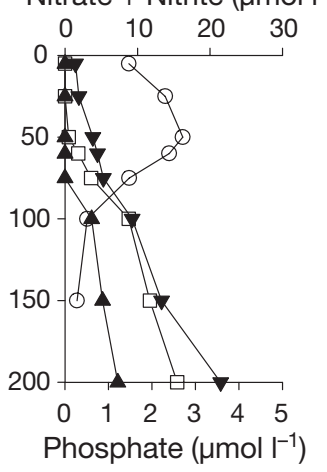

$\begin{array}{llllll}0.0 & 0.1 & 0.2 & 0.3 & 0.4 & 0.5\end{array}$

$\mathrm{Chl} \mathrm{a}\left(\mu \mathrm{g} \mathrm{I}^{-1}\right)$
SEATS

Oxygen ( $\mu \mathrm{mol} \mathrm{kg}{ }^{-1}$ )

50100150200250

Temperature $\left({ }^{\circ} \mathrm{C}\right)$

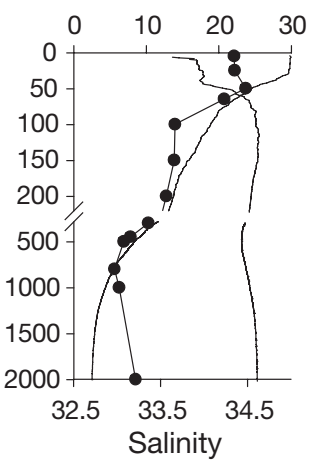

Silicate $\left(\mu \mathrm{mol} \mathrm{I}{ }^{-1}\right)$

$\begin{array}{llll}0 & 10 & 20 & 30\end{array}$

Nitrate + Nitrite $\left(\mu \mathrm{mol} \mathrm{I}{ }^{-1}\right)$

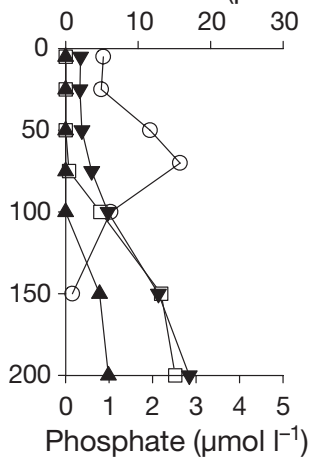

$\begin{array}{llllll}0.0 & 0.1 & 0.2 & 0.3 & 0.4 & 0.5\end{array}$

$\mathrm{Chl} \mathrm{a}\left(\mu \mathrm{g} \mathrm{I}^{-1}\right)$

Fig. 2. Physical and chemical characteristics of the different sites sampled in the South China Sea in summer 2007. Descriptions of stations are as in Fig. 1. The chl a data from samples taken at 6:30 to 7:00 h are plotted. Nutrient concentration values of 0 refer to values below the limit of detection of standard spectrophotometric methods

\section{Prokaryotic abundance and activity inside and outside the cyclonic eddies}

Prokaryotic abundance decreased exponentially with depth, ranging between $4.3 \times 10^{5}$ and $7.5 \times 10^{5}$ cells $\mathrm{ml}^{-1}$ at $50 \mathrm{~m}$ depth and from $0.6 \times 10^{5}$ to $1.2 \times 10^{5}$ cells $\mathrm{ml}^{-1}$ at 1500 to $2000 \mathrm{~m}$ depth. Differences in prokaryotic abundance in the shallow waters ( $\leq 100 \mathrm{~m}$ ) of the 4 sites were apparent. The high prokaryotic abundance at 50 and $100 \mathrm{~m}$ depth in CEP and SEATS (Fig. 3A), respectively, coincided with high chl a concentrations at these depths. At CE1 and CE2, upwelled nutrient-rich water supported a higher phytoplankton biomass in the photic zone, and the chlorophyll maximum layer was shallower (Fig. 2) than outside the eddies. These differences in the distribution of chl a over the euphotic layer between the inside and outside stations coincided with the distribution pattern of prokaryotic abundance at Stns CE1 and CE2 vs. CEP and SEATS. While differences in prokaryotic abundance among the 4 stations were apparent in surface waters, no significant differences were found in the meso- and bathypelagic layers.

Leucine incorporation, as a measure of prokaryotic activity, decreased with depth by 2 orders of magnitude (Table 1). Prokaryotic activity at 50 and $100 \mathrm{~m}$ depth was higher at CEP and SEATS than in the eddy centers. In the deep layers of the water column (800 to $2000 \mathrm{~m}$ depth), prokaryotic activity ranged from 0.43 to 1.02 and from 0.18 to $0.45 \mathrm{pmol}^{-1} \mathrm{~h}^{-1}$ inside (CE1 and CE2) and outside (CEP and SEATS) the eddy centers, 
CE1

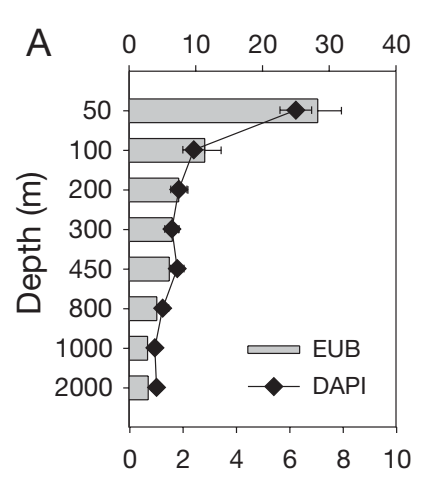

CE2

CEP

Bacterial abundance $\left(\times 10^{4}\right.$ cells $\left.\mathrm{ml}^{-1}\right)$

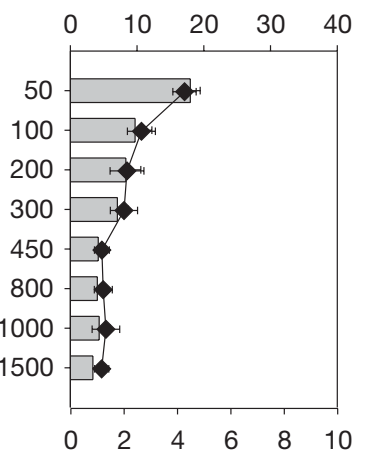

DAPI counts $\left(x 10^{5}\right.$ cells $\left.\mathrm{ml}^{-1}\right)$

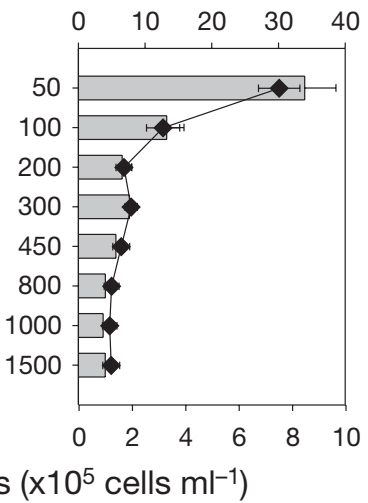

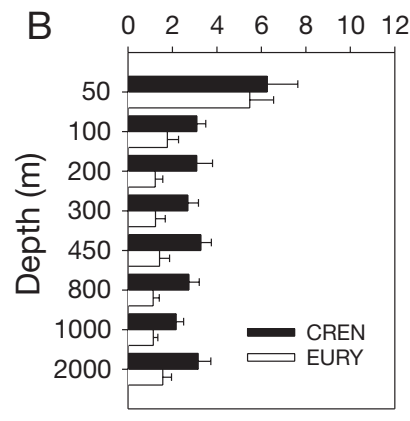
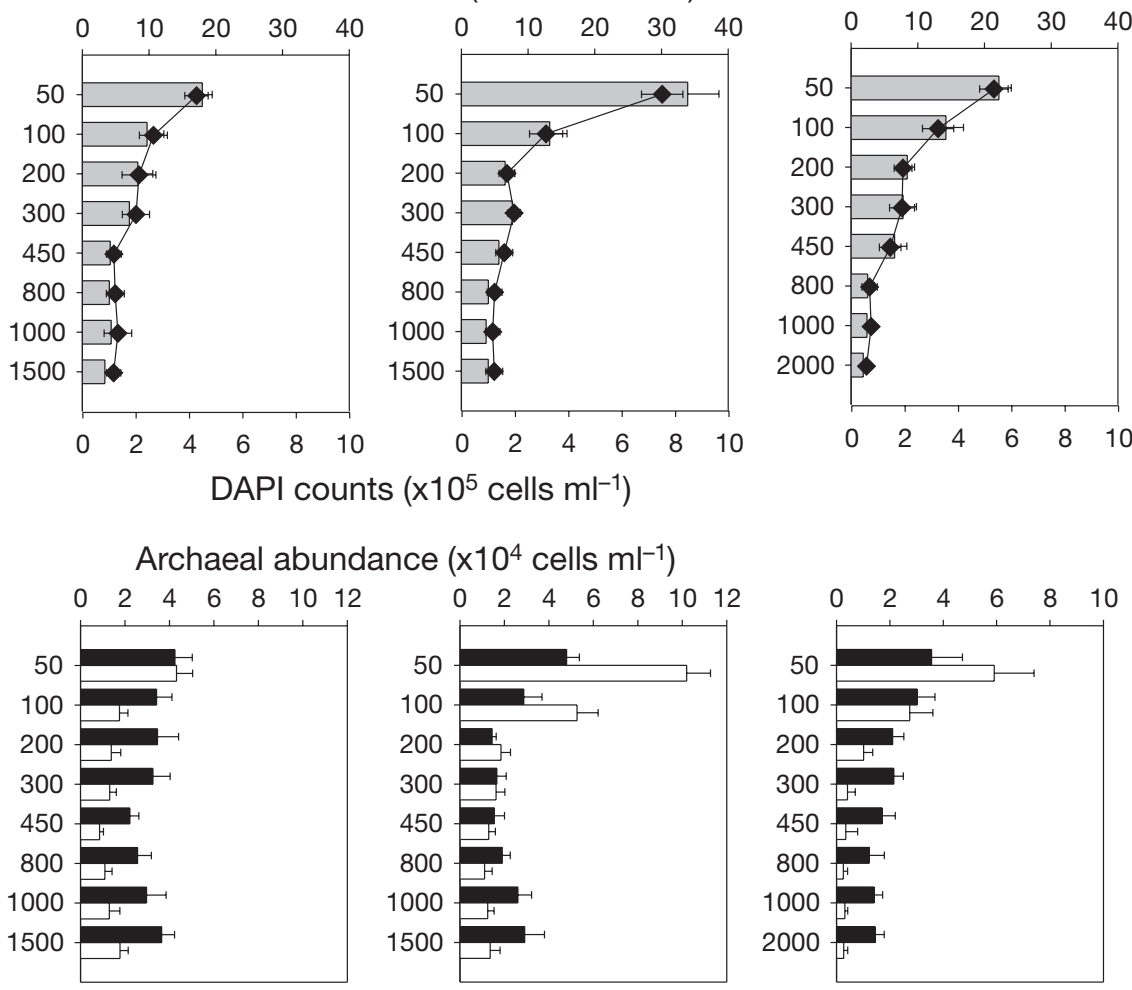

SEATS
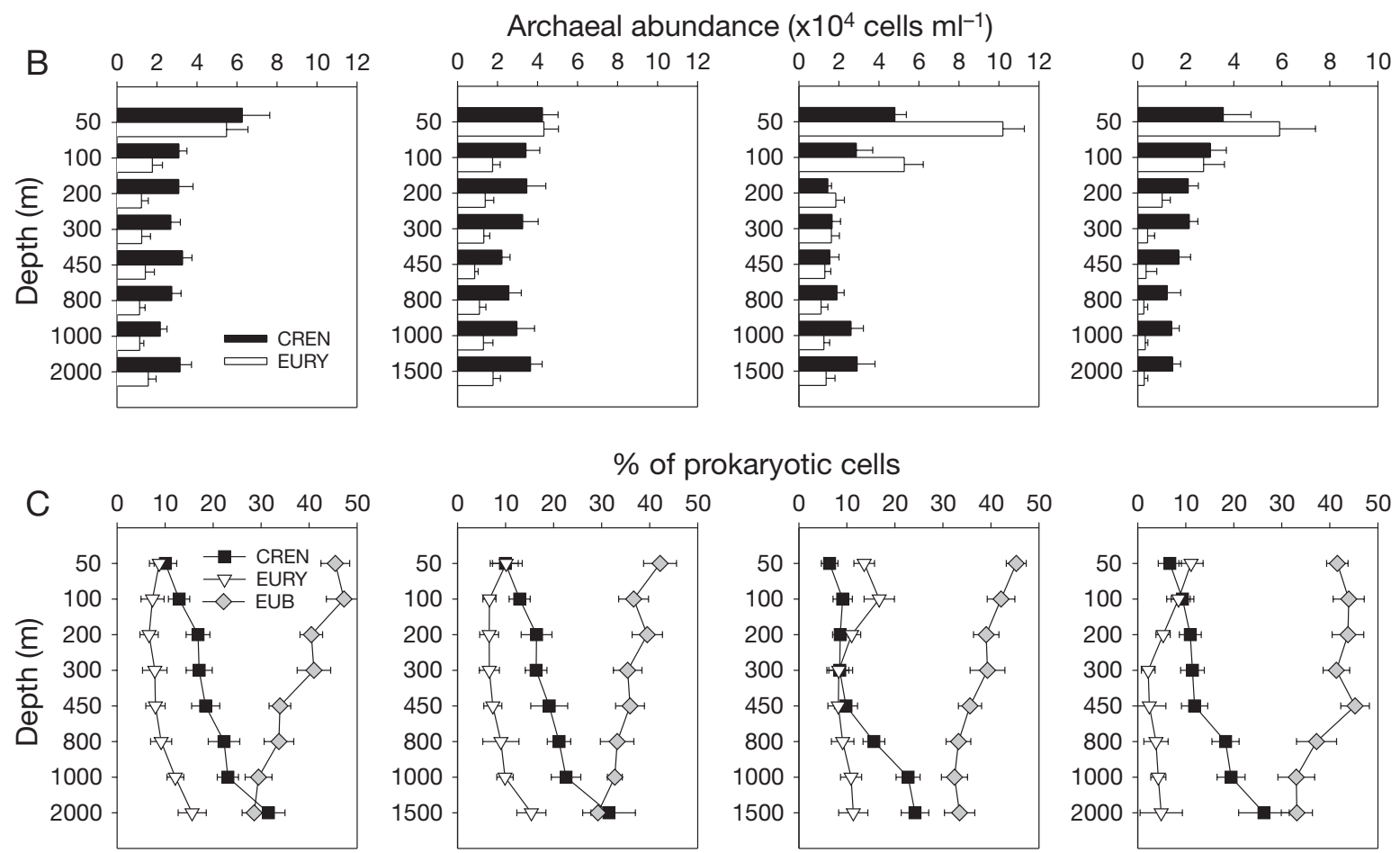

Fig. 3. $(\mathrm{A}, \mathrm{B})$ Abundances (mean \pm SDs) of total prokaryotes (DAPI-stained cells), Bacteria (EUB), marine Crenarchaeota Group I (CREN) and marine Euryarchaeota Group II (EURY), and (C) their contributions to total prokaryotic abundance inside and outside the cyclonic cold eddies in the South China Sea. Descriptions of stations are as in Fig. 1

respectively, while in the intermediate layers (200 to $450 \mathrm{~m}$ depth), prokaryotic activity was not significantly different among the 4 sites.

\section{Prokaryotic community composition inside and outside the cyclonic eddies}

Prokaryotic community structure was examined by CARD-FISH. On average, $63 \pm 5 \%$ of the total number of prokaryotes (DAPI-stained cells) was detected by CARD-FISH with HRP oligonucleotide probes for Bac- teria, marine Crenarchaeota Group I and marine Euryarchaeota Group II. The numbers of DAPI-stained cells before and after CARD-FISH processing were not significantly different (data not shown), indicating that cell loss during CARD-FISH processing was negligible.

Generally, total prokaryotic and bacterial abundance decreased similarly with depth at all 4 sites (Fig. 3A). Also, the abundance of marine Euryarchaeota Group II decreased with depth although in a less pronounced way than Bacteria, while marine Crenarchaeota Group I did not exhibit a depth-related trend (Fig. 3B). There were, however, remarkable detectable differences in 
Table 1. Leucine incorporation rates (Leu) and L-antiomeric aspartic acid (L-Asp) uptake rates $\left(\mathrm{pmol} \mathrm{l}^{-1} \mathrm{~h}^{-1}\right)$. CE1 and CE2: cold-core cyclonic eddies, CEP: cold-core eddy periphery, and SEATS: Southeast Asia Time-Series Study station

\begin{tabular}{|c|c|c|c|c|}
\hline Depth (m) & CE1 & CE2 & CEP & SEATS \\
\hline \multicolumn{5}{|l|}{ Leu } \\
\hline 50 & 17.08 & 13.95 & 18.62 & 14.95 \\
\hline 100 & 3.54 & 3.16 & 4.68 & 4.65 \\
\hline $200-450^{a}$ & $1.07 \pm 0.12$ & $1.29 \pm 0.47$ & $0.86 \pm 0.18$ & $1.09 \pm 0.24$ \\
\hline $800-2000^{a}$ & $0.76 \pm 0.18$ & $0.80 \pm 0.32$ & $0.310 \pm 0.098$ & $0.34 \pm 0.14$ \\
\hline \multicolumn{5}{|l|}{ L-Asp } \\
\hline 50 & 1.76 & 1.03 & 2.41 & 1.41 \\
\hline 100 & 0.41 & 0.34 & 0.71 & 0.71 \\
\hline $200-450^{a}$ & $0.096 \pm 0.013$ & $0.096 \pm 0.021$ & $0.090 \pm 0.028$ & $0.097 \pm 0.054$ \\
\hline $800-2000^{a}$ & $0.026 \pm 0.011$ & $0.0480 \pm 0.0097$ & $0.019 \pm 0.0045$ & $0.025 \pm 0.0049$ \\
\hline
\end{tabular}

the vertical patterns of the relative abundances of the 3 main prokaryotic groups (Fig. 3C). While the contribution of Bacteria to total picoplankton abundance decreased with depth, the relative abundance of marine Crenarchaeota Group I increased, contributing between 6 and $10 \%$ to total picoplankton abundance at $50 \mathrm{~m}$ and from 24 to $32 \%$ at 1500 to $2000 \mathrm{~m}$ depth. The variation in relative abundance of marine Euryarchaeota Group II with depth was small, except in SEATS, where a clear decreasing trend was observed down to $450 \mathrm{~m}$ depth. Marine Crenarchaeota Group I were more abundant than marine Euryarchaeota Group II in meso- and bathypelagic waters at all 4 sites (below $200 \mathrm{~m}$ depth) (Wilcoxon, $\mathrm{p}<0.05$ for both abundance and percentage at each site). In shallow waters $(\leq 100 \mathrm{~m})$, however, Euryarchaeota were more abundant at CEP and SEATS (even more abundant than Crenarchaeota) than at CE1 and CE2 (Fig. 3B). The percentage of total picoplankton identified as marine Crenarchaeota Group I was significantly higher at CE1 and CE2 than at CEP and SEATS throughout the water column (Friedman, p < 0.0001), particularly in the shallow and intermediate waters (up to $\sim 2 \times$ at depths shallower than $800 \mathrm{~m}$ ) (Fig. 3C).

\section{D-Asp vs. L-Asp uptake by the bulk picoplankton community}

Generally, the uptake pattern of L-Asp was similar to leucine incorporation from surface to deep waters at the 4 sites (Table 1). D-Asp uptake rates decreased from shallow waters to the oxygen minimum layer, but increased again in bathypelagic waters (Fig. 4A). The D-Asp:L-Asp uptake ratio of the bulk picoplankton community increased with depth at all study sites, ranging between 0.017 and 0.082 at $50 \mathrm{~m}$ depth and from 0.63 to 1.41 at 1500 to $2000 \mathrm{~m}$ depth. D-Asp:L-Asp uptake ratios $>1$ were measured at 1000 to $2000 \mathrm{~m}$ depth at CE1 and at $1500 \mathrm{~m}$ depth at CE2 (Fig. 4B). Corresponding to the higher bulk D-Asp uptake rates in the 2 eddies (Friedman, $\mathrm{p}<0.0001$ ), the D-Asp:LAsp uptake ratios were significantly higher inside than outside the cyclonic eddies (Friedman, p < 0.0001), especially in intermediate waters (up to $\sim 5 \times$ at 100 to $450 \mathrm{~m}$ depth). The D-Asp:L-Asp uptake ratio decreased exponentially with increasing leucine incorporation rates (Fig. 4C).

\section{Distribution of D-Asp and L-Asp uptake among Archaea and Bacteria}

The distribution of Archaea (marine Crenarchaeota Group I and Euryarchaeota Group II) and Bacteria capable of taking up D-Asp vs. L-Asp was examined at CE1 and CEP by MICRO-CARD-FISH. The recovery efficiencies of picoplankton cells that took up L-Asp and D-Asp were $93 \pm 4$ and $88 \pm 6 \%$, respectively, using the HRP oligonucleotide probes for Bacteria, marine Crenarchaeota Group I and marine Euryarchaeota Group II. The percentage of Bacteria taking up L-Asp and D-Asp out of the total active picoplankton cells decreased with depth from $\sim 60 \%$ at $50 \mathrm{~m}$ depth to $\sim 40 \%$ at 1500 to $2000 \mathrm{~m}$ depth, while the contribution of marine Crenarchaeota Group I to total picoplankton taking up L-Asp and D-Asp increased with depth from $20 \%$ at 50 m depth to 30 and $40 \%$ in the bathypelagic layers, respectively (Fig. 5). The contribution of Crenarchaeota to the total D-Asp+ cells was significantly higher than to the total L-Asp+ cells for both sites (Wilcoxon, p < 0.05 for both CE1 and CEP), in contrast to Euryarchaeota. Significantly higher crenarchaeotal contributions to both total DAsp and L-Asp+ cells were observed at CE1 than at CEP (Wilcoxon, $\mathrm{p}<0.05$ for both D-Asp and L-Asp), while the contribution of marine Euryarchaeota Group II to L-Asp+ cells was significantly higher at CEP than 
CE1

A $\quad 0.00 \quad 0.020 .040 .060 .080 .10$

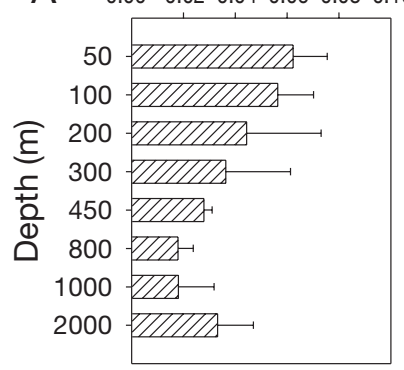

$\begin{array}{llllll}\text { B } & 0.0 & 0.5 & 1.0 & 1.5 & 2.0\end{array}$
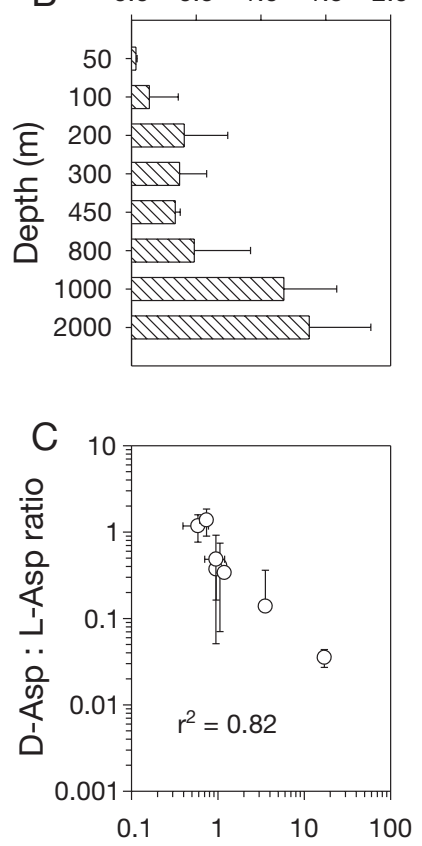

CE2

CEP

D-Asp uptake rate $\left(\mathrm{pmol} \mathrm{I}^{-1} \mathrm{~h}^{-1}\right)$

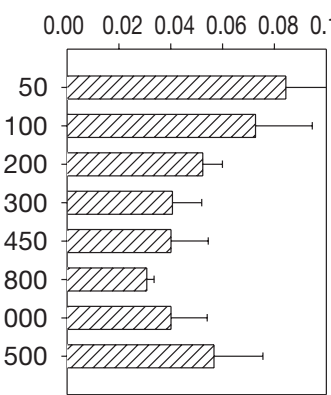

$\begin{array}{llllll}0.00 & 0.02 & 0.04 & 0.06 & 0.08 & 0.10\end{array}$

$\begin{array}{llllll}0.00 & 0.02 & 0.04 & 0.06 & 0.08 & 0.10\end{array}$

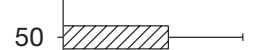

100 DIDTAC

$200-Z 7$

$300-7 \pi$

450

$800-7$

$1000-7$

1500
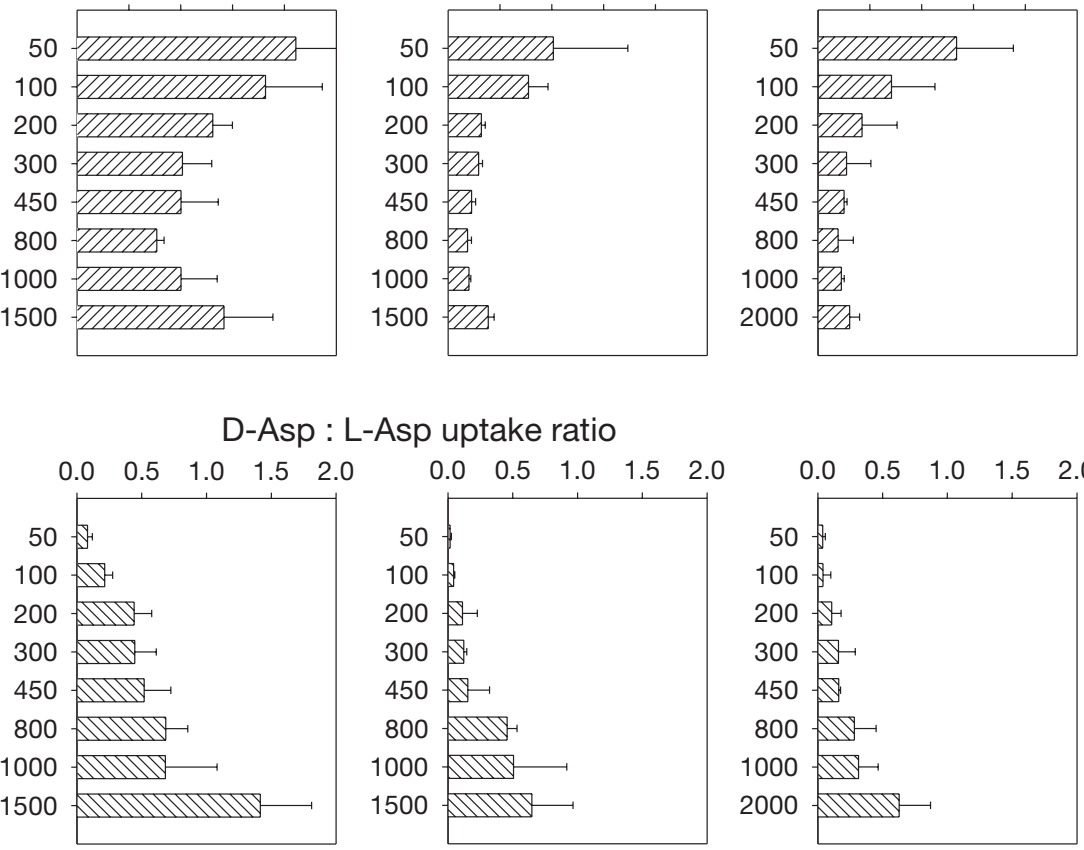

Asp uptake ratio
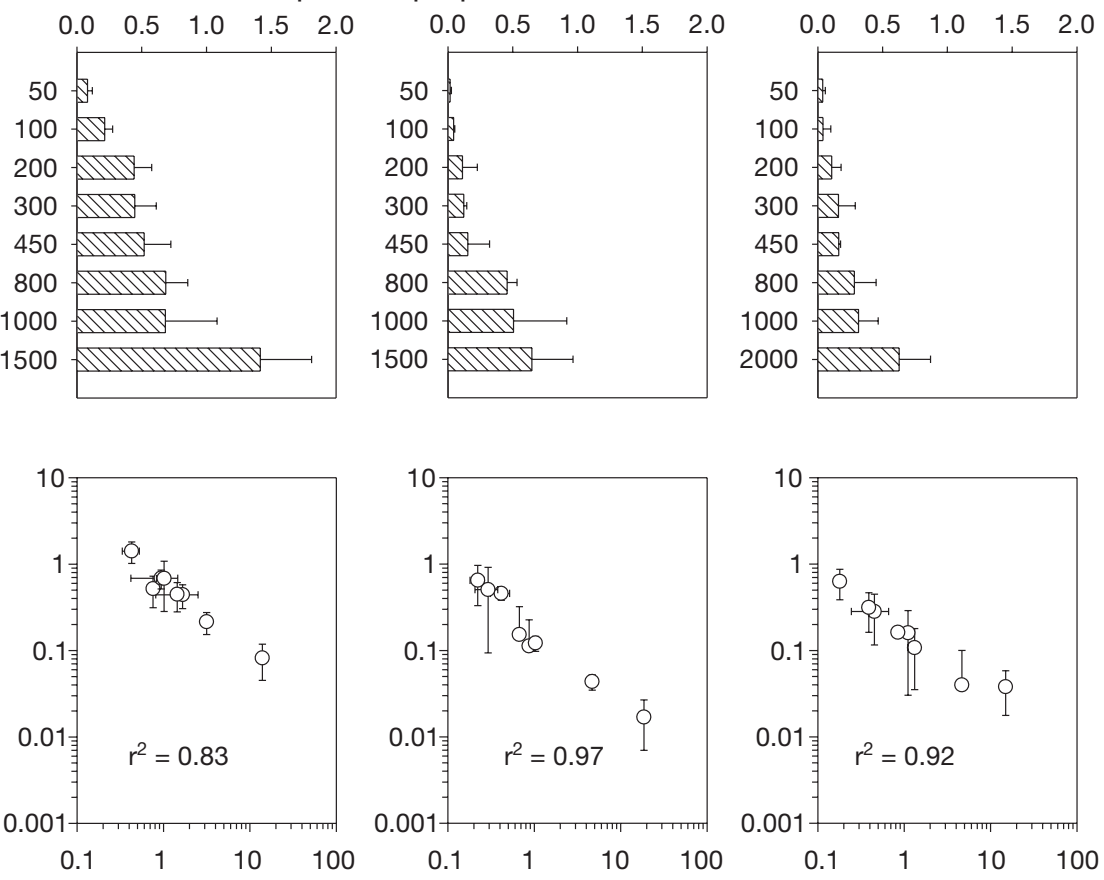

Leu uptake rate $\left(\mathrm{pmol} \mathrm{I}^{-1} \mathrm{~h}^{-1}\right)$

Fig. 4. (A) D-Asp (aspartic acid) uptake rates (pmol $\mathrm{l}^{-1} \mathrm{~h}^{-1}$ ), (B) D-Asp:L-Asp uptake ratios, and (C) correlation between D-Asp:LAsp uptake ratios and leucine (leu) incorporation rates of the bulk prokaryotic community inside and outside the cyclonic cold eddies in the South China Sea. The fitting function used between the D-Asp:L-Asp uptake ratio and leucine incorporation is $y=\mathrm{ae}^{\mathrm{bx}}$. Descriptions of stations are as in Fig. 1. Error bars indicate $\pm \mathrm{SD}$

at CE1 (Wilcoxon, $\mathrm{p}<0.05)$. No significant differences in euryarchaeotal contribution to D-Asp+ cells between the 2 sites (Wilcoxon, $p>0.1$ ) were found.

The fractions of D-Asp and L-Asp+ Bacteria, Crenarchaeota and Euryarchaeota of the total number of Bacteria, Crenarchaeota and Euryarchaeota were also determined (Table 2). Generally, the L-Asp active fractions were significantly higher than the D-Asp active fractions of the total bacterial, crenarchaeal and euryarchaeal cells at the 2 sites (Wilcoxon, $\mathrm{p}<0.05$ for the 3 groups in both CE1 and CEP). The L-Asp active fractions of Bacteria, marine Crenarchaeota Group I and Euryarchaeota
Group II decreased with depth, while the D-Asp active fractions did not exhibit depth-related trends $(<15 \%)$. Of the total picoplankton cells taking up L-Asp, marine Crenarchaeota Group I and marine Euryarchaeota Group II accounted for $\sim 20 \%$ in the shallow waters of CE1 and CEP (Fig. 5); however, $~ 50 \%$ of all the Crenarchaeota and Euryarchaeota took up L-Asp (Table 2). In the bathypelagic waters of both sites, only $<10 \%$ of the total crenarchaeotal and euryarchaeotal cells took up L-Asp. More than $45 \%$ of Bacteria were L-Asp+ in shallow waters, compared to $<10 \%$ of Bacteria being L-Asp+ in deep waters. The ratios of D-Asp:L-Asp+ cells increased 


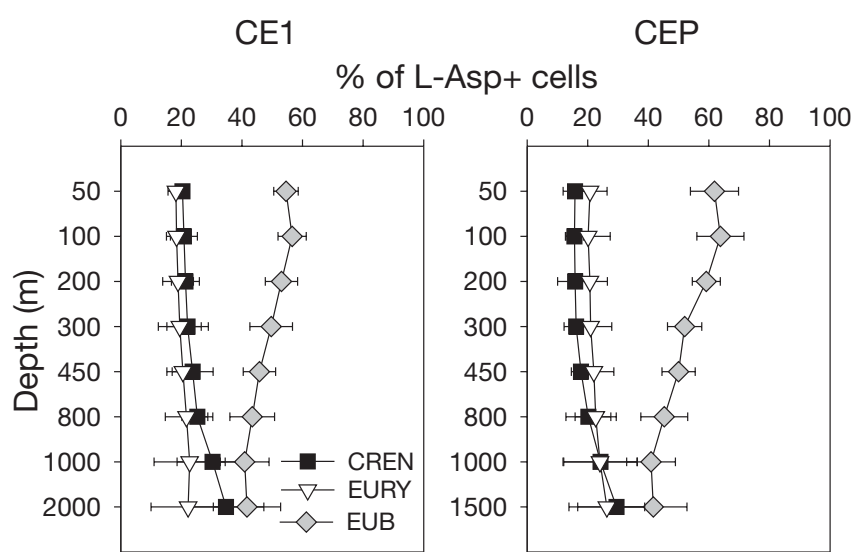

$\%$ of D-Asp+ cells

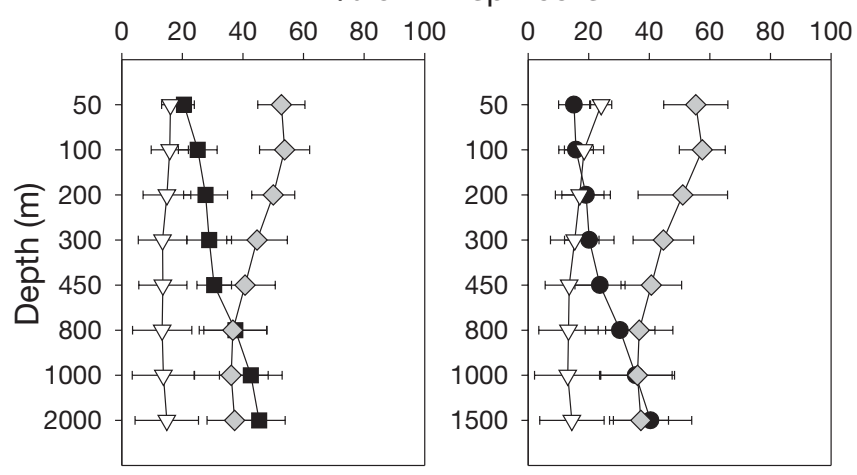

Fig. 5. Contributions (\%, mean $\pm \mathrm{SD}$ ) of Bacteria (EUB), marine Crenarchaeota Group I (CREN) and marine Euryarchaeota Group II (EURY) to the total D- and L-Asp+ cells of communities. CE1: cold-core cyclonic eddy \#1; CEP: coldcore cyclonic eddy periphery. The value of $100 \%$ is the total D- or L-Asp+ DAPI-stained cells. Asp: aspartic acid

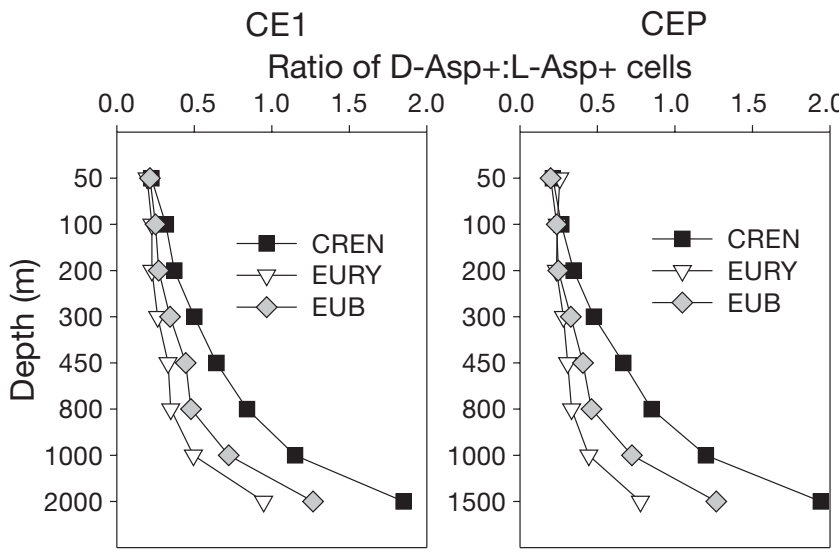

Fig. 6. Ratio of D-Asp:L-Asp (aspartic acid) active cells in Bacteria (EUB), marine Crenarchaeota Group I (CREN) and marine Euryarchaeota Group II (EURY). CE1: cold-core cyclonic eddy \#1; CEP: cold-core cyclonic eddy periphery. Values were calculated by dividing the means of D-Asp+ fractions by the means of L-Asp+ fractions of major prokaryotic groups (no error bars). The value of $100 \%$ is the total crenarchaeotal, euryarchaeotal or bacterial probe positive DAPIstained cells

and SEATS (Friedman, $\mathrm{p}<0.01$ ), especially in the shallow and intermediate waters $(\leq 500 \mathrm{~m})$ (Fig. 7). The ratio of humic-like FDOM to bulk DOC concentrations (data not shown) was higher in the shallow/intermediate waters (25 to $450 \mathrm{~m}$ depth) in the eddies (range: 9.8 to $18 \mathrm{QSU}(\mu \mathrm{M} \mathrm{DOC})^{-1}$ ) than outside the eddies (range: 2.3 to 15 QSU $(\mu \mathrm{M} \mathrm{DOC})^{-1}$ ) (Wilcoxon, $\mathrm{p}<0.05$ ). For bathypelagic waters, no significant difference in DOCnormalized fluorescence was found between stations inside and outside the eddies. with depth at both CE1 and CEP for Bacteria, marine Crenarchaeota Group I and Euryarchaeota Group II (Fig. 6). This ratio increased more with depth in marine Crenarchaeota Group I than in Bacteria and marine Euryarchaeota Group II (Friedman, p < 0.0001 for both CE1 and CEP). However, no significant differences in the ratio D-Asp:L-Asp+ cells of the 3 prokaryotic groups were found between the 2 sites (Wilcoxon, $\mathrm{p}>0.5$ for Crenarchaeota and Euryarchaeota; p > 0.05 for Bacteria).

\section{FDOM distribution inside and outside the cyclonic eddies}

Humic-type FDOM was generally higher at CE1 and CE2 than at CEP
Table 2. Fraction (\%, mean of duplicate measurements) of D-Asp+ and L-Asp+ Bacteria (EUB), Crenarchaeota (CREN) and Euryarchaeota (EURY) of the total number of Bacteria, Crenarchaeota and Euryarchaeota

\begin{tabular}{|lrrrrrr|}
\hline \multirow{2}{*}{ Depth (m) } & \multicolumn{2}{c}{ EUB } & \multicolumn{2}{c}{ CREN } & \multicolumn{2}{c|}{ EURY } \\
& D-Asp+ & L-Asp+ & D-Asp+ & L-Asp+ & D-Asp+ & L-Asp+ \\
\hline Stn CE1 & & & & & & \\
50 & 9.66 & 45.17 & 11.56 & 51.76 & 10.34 & 52.87 \\
100 & 10.29 & 41.15 & 10.50 & 33.15 & 13.04 & 57.61 \\
200 & 8.77 & 32.46 & 7.93 & 21.34 & 13.21 & 58.49 \\
300 & 8.40 & 24.43 & 9.09 & 18.18 & 10.29 & 38.97 \\
450 & 7.25 & 16.31 & 9.28 & 14.43 & 10.26 & 31.03 \\
800 & 6.11 & 12.78 & 8.75 & 10.42 & 8.16 & 23.47 \\
1000 & 8.13 & 11.25 & 8.98 & 7.81 & 7.50 & 15.18 \\
2000 & 11.45 & 9.04 & 12.33 & 6.67 & 8.37 & 8.84 \\
Stn CEP & & & & & & \\
50 & 14.49 & 88.31 & 11.22 & 52.79 & 8.20 & 31.88 \\
100 & 8.98 & 37.89 & 7.69 & 28.85 & 5.41 & 22.39 \\
200 & 10.63 & 42.95 & 14.06 & 40.63 & 9.59 & 40.75 \\
300 & 7.33 & 22.33 & 10.50 & 22.00 & 9.20 & 32.76 \\
450 & 10.30 & 25.32 & 14.00 & 21.00 & 11.11 & 36.11 \\
800 & 9.04 & 19.59 & 10.90 & 12.82 & 8.24 & 24.73 \\
1000 & 6.28 & 8.70 & 7.93 & 6.61 & 6.90 & 15.52 \\
1500 & 10.22 & 8.06 & 11.62 & 5.99 & 9.09 & 10.69 \\
& & & & & & \\
\hline
\end{tabular}




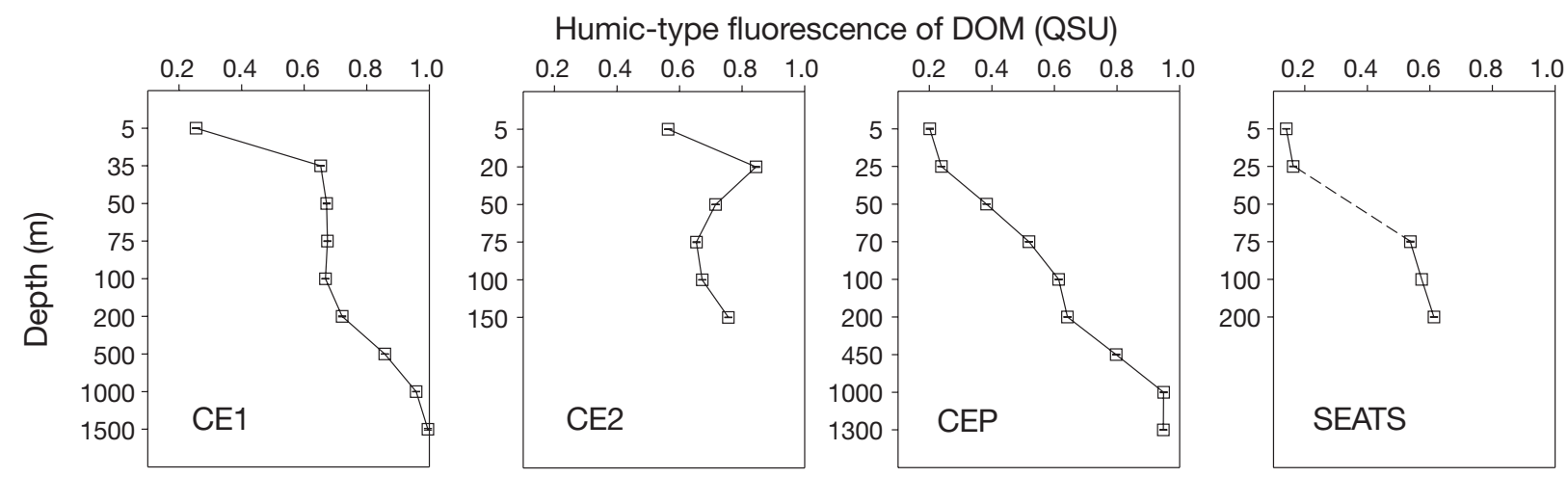

Fig. 7. Vertical distribution of fluorescent dissolved organic matter (FDOM). Descriptions of stations are as in Fig. 1. Only samples from the upper ocean shallower than $200 \mathrm{~m}$ were taken for FDOM fluorescence measurement at CE2 and SEATS. Error bars indicate $\pm \mathrm{SD}$. QSU: quinine sulfate unit

\section{DISCUSSION}

The SCS is a semi-enclosed marginal sea with a deep basin in the tropical-subtropical western North Pacific (Fig. 1). It is characterized by oligotrophic conditions, a shallow mixed layer and nutricline, low primary production (23 to $42 \mathrm{mmol} \mathrm{C} \mathrm{m}^{-2} \mathrm{~d}^{-1}$ ) (Liu et al. 2002) and low export production (1 to $3.4 \mathrm{mmol} \mathrm{C} \mathrm{m}^{-2}$ $\mathrm{d}^{-1}$ ) (Chen et al. 1999). Driven by the prevailing monsoonal wind stress, mesoscale eddies are active in, and characterize the hydrography of, the SCS (Hwang \& Chen 2000, Wang et al. 2003).

During the GOE-2 cruise, 2 well-developed coldcore cyclonic eddies were tracked. Apparently, the differences in water mass movement inside and outside the cyclonic eddies led to distinct temperature, salinity, nutrient and dissolved oxygen characteristics (Fig. 2), which consequently modified picoplankton community composition and activity.

\section{Picoplankton community composition inside and outside cyclonic eddies}

In this study, the recovery efficiency (sum of Bacteria, marine Crenarchaeota Group I and marine Euryarchaeota Group II as a percentage of DAPI-stained cells) ranged between 53 and $76 \%$, which is comparable with those reported for North Atlantic meso- and bathypelagic waters (Teira et al. 2006a, Varela et al. 2008). There is one methodological difference between this study and the previous studies, as we used the oligonucleotide probe mix of Cren537 and Cren554 (De-Corte et al. 2009) to enumerate Crenarchaeota, whereas the previous studies used only Cren537. This might have resulted in a higher percentage of DAPIstained cells identified as Crenarchaeota in the present study than reported for the subtropical Atlantic (Varela et al. 2008). Although the multiple probes targeted Bacteria and Crenarchaeota, the recovery efficiency was well below $100 \%$ of DAPI-stained cells. The explanation might be that some cells did not contain a sufficient number of ribosomes, although the signal amplification procedure was used in this study. A certain fraction of DAPI-stainable cells might also be dormant or dead, and hence did not contain any ribosome as shown previously (Heissenberger et al. 1996).

Our results revealed a steady increase in the contribution of marine Crenarchaeota Group I to the total picoplankton abundance from shallow layers down to bathypelagic waters in the SCS (Fig. 3C), confirming the previously reported general distribution pattern of marine Crenarchaeota Group I with depth (DeLong et al. 1999, Karner et al. 2001, Herndl et al. 2005, Teira et al. 2006a, Varela et al. 2008); a contrasting pattern was found for Bacteria, which is similar to previous studies in the Pacific (DeLong et al. 1999, Karner et al. 2001). There is growing evidence that Crenarchaeota are particularly associated with low-oxygen environments such as upwelling areas (Coolen et al. 2007, Lam et al. 2007). In the present study, the contribution of marine Crenarchaeota Group I to total picoplankton abundance throughout the water column was significantly higher inside (up to $31 \%$ of DAPI-stained cells) than outside the cyclonic eddies (Friedman, $p<0.0001$ ), especially in shallow and intermediate waters (upper $800 \mathrm{~m}$, up to $\sim 2 \times$ ) (Fig. 3C), coinciding with lower oxygen concentrations inside than outside the cyclonic eddies (Fig. 2). Concurrently, significantly higher concentrations of nitrous oxide were found inside than outside the eddies, especially in intermediate waters shallower than $450 \mathrm{~m}$ depth (H. Lin \& M. Dai unpubl.). Also, archaeal amoA gene copy numbers were at least one order of magnitude higher than betaproteobacterial amoA gene copy numbers (A. Hu \& N. Jiao unpubl.). This suggests that Crenarchaeota might play a 
significant role in the nitrification process (Wuchter et al. 2006). Thus, the high contribution of marine Crenarchaeota Group I to total picoplankton abundance inside the cyclonic eddies might reflect their importance as nitrifiers in the cyclonic eddies system. However, the Crenarchaeota we detected in the present study were largely heterotrophic as indicated by the high abundance of Asp+ Crenarchaeota.

Marine Euryarchaeota Group II contributed 2 to $16 \%$ to the picoplankton abundance throughout the water column in the SCS, which is comparable with the reported range of 2 to $15 \%$ in the Pacific (DeLong et al. 1999). Compared to other oceanic regimes, our data are slightly lower than that reported by Teira et al. (2006a) for the eastern North Atlantic (averaging 9\%), and higher than that reported for the (sub)tropical North Atlantic (Varela et al. 2008) and for the western Arctic Ocean (Kirchman et al. 2007). There is some evidence that Euryarchaeota are prominent in coastal waters (Stoica \& Herndl 2007) and are positively correlated with chlorophyll concentration (Herfort et al. 2007). In our study, the higher abundance of marine Euryarchaeota Group II at 50 and $100 \mathrm{~m}$ in CEP and SEATS, which are located outside the cyclonic eddies, coincides with higher chlorophyll concentrations, while marine Euryarchaeota Group II were less abundant in the shallow waters of CE1 and CE2. Deepwater prokaryotic plankton were introduced into the upper ocean due to cyclonic eddy-driven upwelling.

\section{Prokaryotic activity as measured by D-Asp vs. L-Asp uptake inside and outside cyclonic eddies}

While L-enantiomeric amino acids constitute the vast majority of the total amino acid pool in the ocean and are efficiently taken up by the heterotrophic prokaryotic community (Ouverney \& Fuhrman 2000), D-amino acids are considered refractory, suggesting that the D:L-amino acid ratio in the DOM pool might be an indicator of the diagenetic state of the oceanic DOM (Amon et al. 2001, Nagata et al. 2003). Thus, differences in the D-Asp:L-Asp uptake ratio by prokaryotes between stations inside and outside the cyclonic eddies might be due to differences in the composition of the DOM pool between the 2 systems. Our measurements on the uptake ratio of D-Asp:L-Asp of the bulk prokaryotic community support the general vertical pattern of increase with depth as previously described for the Atlantic (Pérez et al. 2003, Teira et al. 2006a, Varela et al. 2008) (Fig. 4B). A significantly higher D-Asp:L-Asp uptake ratio was found inside than outside the cyclonic eddies (Friedman, p < 0.0001), especially in intermediate waters (100 to $450 \mathrm{~m}$ depth, up to $\sim 5 \times$ ). Our data further indicate that the increase in the D-Asp:L-Asp uptake ratio from surface to deep waters and the higher uptake ratio within the cyclonic eddies are largely caused by marine Crenarchaeota Group I that efficiently take up D-Asp (Fig. 5). Substantial differences in the utilization of enantiomeric amino acids among the major prokaryotic groups and the higher D-Asp:L-Asp uptake ratios inside than outside the cyclonic eddies might reflect subtle differences in the DOM pool of the 2 systems. Deep-water DOM was introduced into the upper mesopelagic waters together with prokaryotic plankton due to cyclonic eddy-driven pumping.

We observed positive correlations between the abundance of Bacteria and Crenarchaeota and their contribution to the total D-Asp and L-Asp+ cells ( $\mathrm{p}<$ 0.01) (Fig. 8). These correlations suggest that the contribution of Bacteria and Crenarchaeota to total activity can be largely explained by their abundance. However, significant differences were found in the slopes of the regression (Fig. 8). The slopes of the regression between the contributions of Crenarchaeota to total picoplankton abundance and D-Asp+ cells are $>1$, while the slopes for L-Asp uptake are $<1$, indicating that the abundant Crenarchaeota in the bathypelagic realm contribute more to D-Asp than to L-Asp uptake. The slopes of the regression between the contributions of Bacteria to total picoplankton abundance and D-Asp or L-Asp uptake-active cells are $>1$ at CEP, but $\sim 1$ at CE1, indicating that abundant Bacteria in the upper ocean contribute more to D- or L-Asp uptake outside than inside the eddy, coinciding with higher prokaryotic abundance and production in the shallow waters of the cyclonic eddy periphery (Table 1, Fig. 3). However, there was no significant difference between the 2 sites for Crenarchaeota.

We also calculated the ratio of D-Asp:L-Asp+ cells in bacterial and archaeal groups (Fig. 6). As expected, marine Crenarchaeota Group I exhibited a higher ratio of D-Asp:L-Asp active cells than marine Euryarchaeota Group II and Bacteria in meso- and bathypelagic waters (Friedman, p $<0.0001$ for both CE1 and CEP), although no significant differences were found between the 2 systems (Fig. 6). However, significant relationships $(p<0.01)$ were observed between the relative abundance and the ratio of D-Asp:L-Asp+ cells in Bacteria and Crenarchaeota, and a significant difference was found between the 2 stations for Crenarchaeota (Wilcoxon, p < 0.05) (Fig. 9). For marine Crenarchaeota Group I, the tighter positive correlation and the higher slope inside than outside the cyclonic eddies suggest that their abundance is more closely controlled by their D-Asp uptake-activity. In contrast, there was a negative correlation between the relative abundance and the D-Asp:L-Asp active fraction of Bacteria (Fig. 9). There was also no significant difference between the 2 stations for Bacteria. 

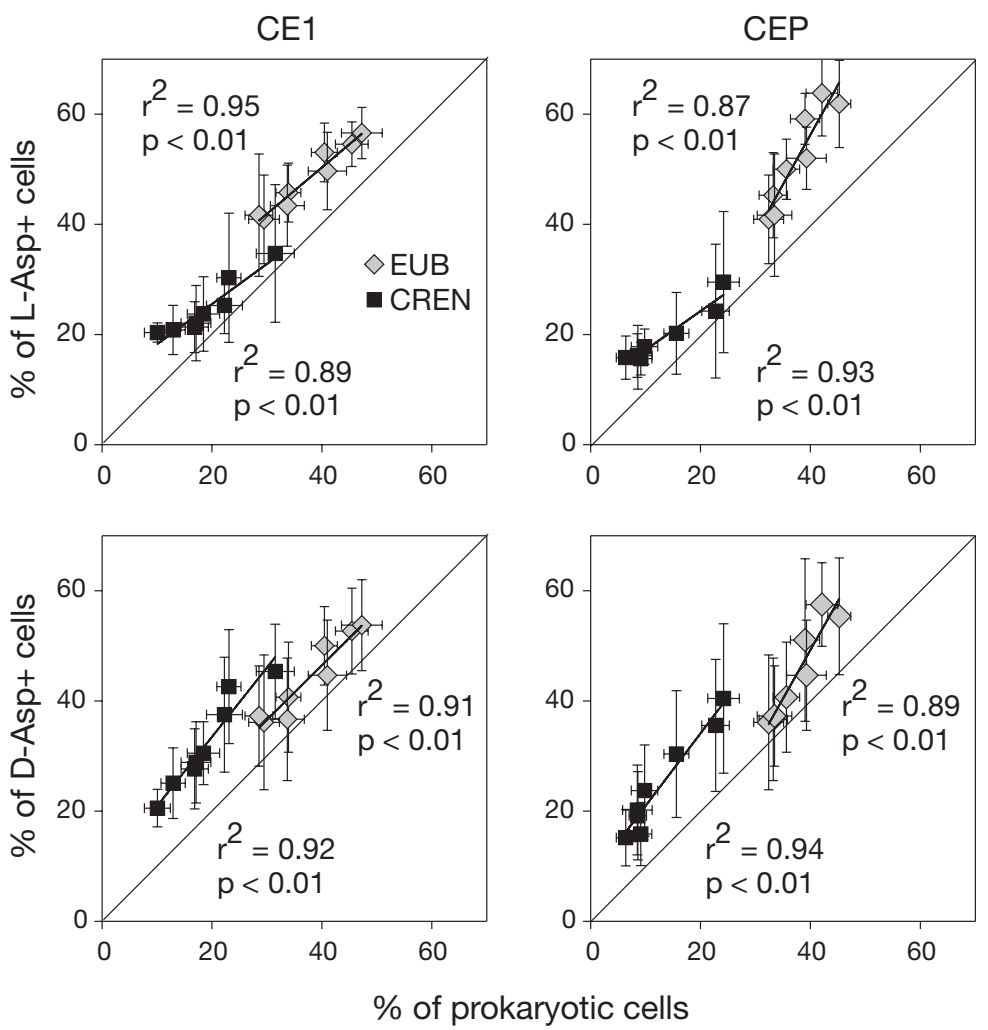

Fig. 8. Relationship between the relative abundance of Bacteria (EUB) and marine Crenarchaeota (CREN) Group I and their contributions to the total D- and L-Asp+ cells. CE1: cold-core cyclonic eddy \#1; CEP: cold-core cyclonic eddy periphery. Diagonal lines indicate a 1:1 relationship. Error bars indicate \pm SD. Asp: aspartic acid
Relating FDOM and picoplankton community structure and D- vs. L-Asp uptake

With higher D-Asp:L-Asp uptake ratios indicating the utilization of old, more refractory DOM (Pérez et al. 2003, Teira et al. 2006a), the higher D-Asp:L-Asp uptake ratio at shallower depths inside the cyclonic eddies suggests the presence of more refractory DOM inside than outside the cyclonic eddies. The greater crenarchaeotal contribution indicates that the $\mathrm{Cre}$ narchaeota were efficiently using relatively refractory DOM inside the cyclonic eddies. With humic substances being considered as biologically recalcitrant (McKnight \& Aiken 1998, Obernosterer \& Herndl 2000), our measurements of FDOM (Fig. 7) and the estimated contribution of humic-like FDOM to bulk DOC concentrations (between 25 and $450 \mathrm{~m}$ depth inside the eddies: 9.8 to $18 \mathrm{QSU}(\mu \mathrm{M} \mathrm{DOC})^{-1}$; outside: 2.3 to $15 \mathrm{QSU}(\mu \mathrm{M} \mathrm{DOC})^{-1}$ ) confirm the difference in the distribution of this refractory fraction between stations inside and outside the cyclonic eddies, particularly in the shallow and mesopelagic waters (Fig. 7). Amino acids associated with humic material represent an important fraction of the amino acid pool in marine waters (Lytle \& Perdue 1981, Hubberten et al. 1994). To further examine whether the higher D-Asp:L-Asp uptake ratio and crenarchaeotal

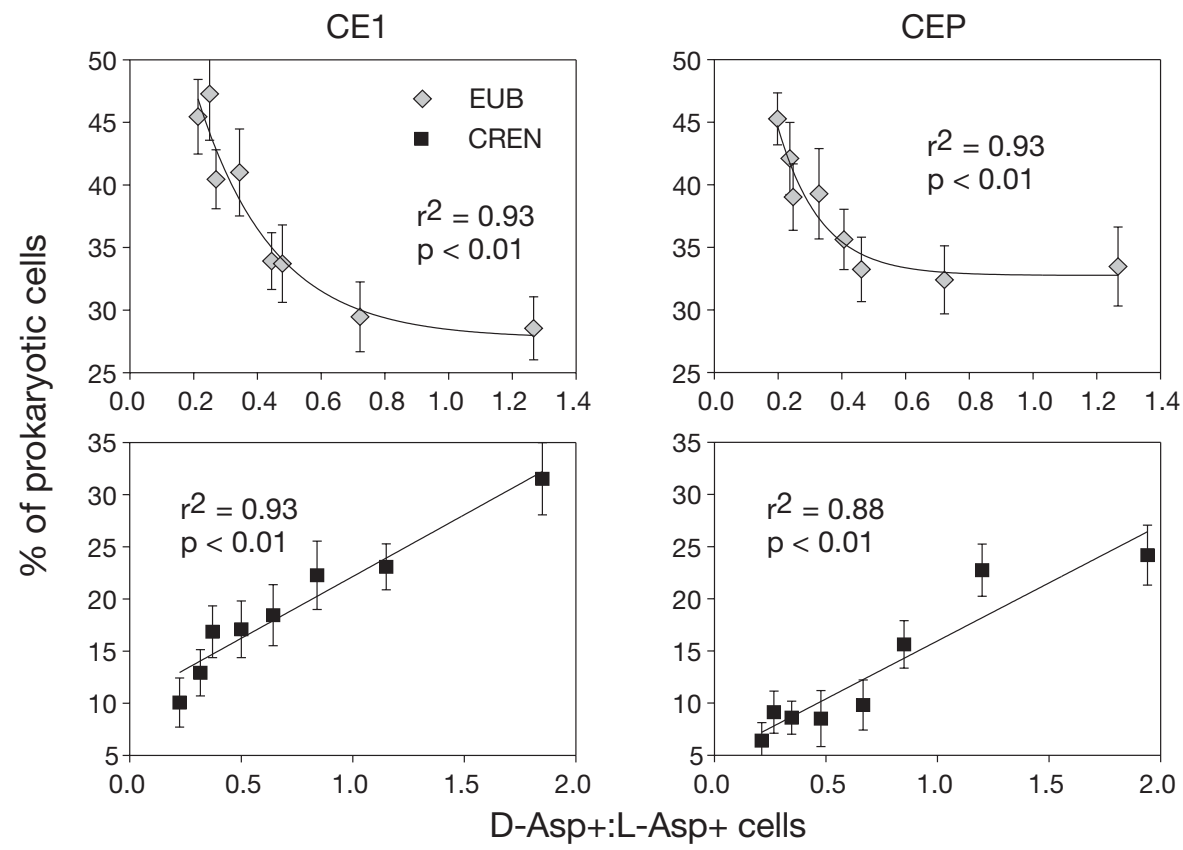

Fig. 9. Correlation between the relative abundance and the ratio of D-Asp+:L-Asp+ cells of Bacteria (EUB) and marine Crenarchaeota Group I (CREN). A linear regression was used for Crenarchaeota. The fitting function used for Bacteria is: $y=y 0+a e^{-b x}$. CE1: cold-core cyclonic eddy \#1; CEP: cold-core cyclonic eddy periphery. Error bars indicate \pm SD 
contribution can be explained by the higher refractory DOM inside the cyclonic eddy, we plotted the contributions of Crenarchaeota to total picoplankton abundance and D-Asp+ cells as well as the D-Asp:L-Asp uptake ratio of the bulk prokaryotic community against FDOM (Fig. 10B-D). Significant positive correlations were observed in all cases $(p<0.01)$, suggesting the possible influence of the variable DOM pool composition on the picoplankton community.

In order to estimate the levels of preformed FDOM in source waters or the degree of water mixing (Yamashita \& Tanoue 2008), we related the fluorescence intensity of FDOM and AOU inside and outside the cyclonic eddies (below $50 \mathrm{~m}$ depth), and found evidence of linear relationships ( $\mathrm{p}<0.01)$ (Fig. 10A). The positive correlation indicates that FDOM is produced in situ in the ocean's interior in association with the remineralization of biogenic sinking particles, and that FDOM is resistant to biological degradation on timescales of this correlation (Yamashita \& Tanoue 2008). However, the higher $x$-axis intercept of the linear correlation inside the cyclonic eddies, as AOU should be near zero, represents allochthonous humic substances elevating the intercept (Yamashita \& Tanoue 2008). Thus, our results suggest that the difference in FDOM distribution between stations inside and outside the cyclonic eddies is induced by intrusion of old deep water masses with high humic material into the upper ocean through water upwelling inside the cyclonic eddies.

The observations we report here confirm the shifts in the distribution of, and D- vs. L-amino acid uptake by, the prokaryotic community with depth in the SCS, as previously reported in the Atlantic. However, the higher D-Asp:L-Asp uptake ratio and crenarchaeotal contribution found inside than outside the cold-core eddy system, suggest that differences in the composition of the DOM pool and of the prokaryotic communities between the 2 systems are caused by cyclonic eddy-driven pumping. This eddy-pumping ultimately leads to a more prominent role of Crenarchaeota in the cycling of carbon and nitrogen in intermediate waters inside than outside the cyclonic eddy system in the SCS. The comparison between MICRO-CARD-FISH data and FDOM indicates that the differences in the distribution and activity of picoplankton communities between the 2 systems can be explained by a higher fraction of refractory DOM at shallower depths inside the cyclonic eddy due to water upwelling.

In summary, the results presented in this paper highlight the importance of hydrodynamic conditions and features in structuring microbial planktonic communities. This aspect is frequently inadequately considered in studies dealing with the composition and activity of marine microbial food webs.
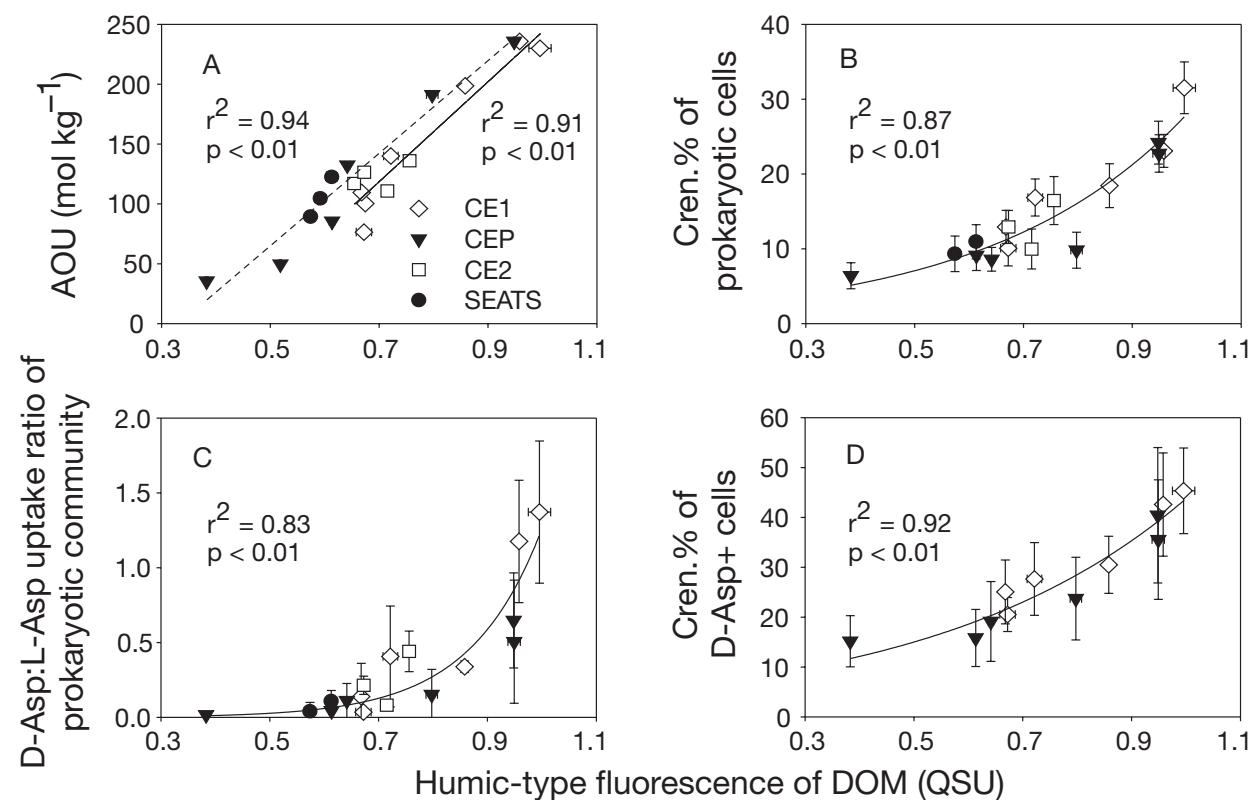

Fig. 10. (A) Relationships between fluorescent dissolved organic matter (FDOM) and apparent oxygen utilization (AOU). Descriptions of stations are as in Fig. 1. A linear regression was used between AOU and FDOM within (CE1 and CE2, —) and outside (CEP and SEATS, -- -) the eddies. The additional data from 70 or $75 \mathrm{~m}$ at CE1, CE2, and CEP and from $150 \mathrm{~m}$ at SEATS were also plotted, although we did not take samples for MICRO-CARD-FISH (microautoradiography combined with catalyzed reporter deposition fluorescence in situ hybridization) measurement for these layers. (B) Contribution of Crenarchaeota (Cren.) to total prokaryotic abundance vs. FDOM. (C) D-Asp:L-Asp (aspartic acid) uptake ratio of the bulk prokaryotic community vs. FDOM. (D) Contribution of Crenarchaeota to D-Asp+ cells vs. FDOM. Data plotted are from only 2 stations (CE1 and CEP) where we took samples for microautoradiography. The fitting function used in B,C and D is $y=\mathrm{ae}^{\mathrm{bx}}$. Error bars indicate SDs. QSU: quinine sulfate unit 
Acknowledgements. We thank the captain and crew of the RV 'Dongfanghong' \#2; Y. Chen, A. Y. Hu and N. Xiao for assistance in collecting the samples; B. Q. Huang for providing the chlorophyll data; J. Y. Hu for providing the ADCP data; and Z. Y. Sun and J. Zhu for providing the temperature and salinity data. We also thank X. H. Guo, L. F. Wang and J. $\mathrm{H}$. Chen for the dissolved oxygen, nutrient and dissolved organic carbon measurements, and T. Yokokawa for assistance in AOU calculation. This work was supported by the NSFC Project 40806052, the NSFC 'Group of Excellent' Project 40521003 and a Nuffic Huygens Award to Y.Z.. G.J.H. and E.S. were supported by the Dutch Science Foundation (ALW-NWO). N.Z.J. was supported by the 973 Project 2007 CB815904 and the Key NSPF Project 40632013.

\section{LITERATURE CITED}

Agogué H, Brink M, Dinasquet J, Herndl GJ (2008) Major gradients in putatively nitrifying and non-nitrifying Archaea in the deep North Atlantic. Nature 456:788-791

Allen CB, Kandat J, Laws EA (1996) New production and photosynthetic rates within and outside a cyclonic mesoscale eddy in the North Pacific subtropical gyre. Deep Sea Res I 43:917-936

Amon RMW, Fitznar HP, Benner R (2001) Linkages among the bioreactivity, chemical composition, and diagenetic state of marine organic matter. Limnol Oceanogr 46:287-297

Benitez-Nelson CR, Bidigare RR, Dickey TD, Landry MR and others (2007) Mesoscale eddies drive increased silica export in the subtropical Pacific Ocean. Science 316: $1017-1021$

Carpenter JH (1965) The Chesapeake Bay Institute technique for the Winkler dissolved oxygen method. Limnol Oceanogr 10:141-143

Chen J, Wiesner MG, Wong HK, Zheng L, Xu L, Zheng S (1999) Vertical changes of POC flux and indicators of early degradation of organic matter in the South China Sea. Sci China D Earth Sci 42:120-128

Coolen MJL, Abbas B, Bleijswijk JV, Hopmans EC, Kuypers MMM, Wakeham SG, Damste JSS (2007) Putative ammonia-oxidizing Crenarchaeota in suboxic waters of the Black Sea: a basin-wide ecological study using $16 \mathrm{~S}$ ribosomal and functional genes and membrane lipids. Environ Microbiol 9:1001-1016

- De-Corte D, Yokokawa T, Varela MM, Agogue H, Herndl GJ (2009) Spatial distribution of Bacteria and Archaea and amoA gene copy numbers throughout the water column of the eastern Mediterranean Sea. ISME J 3:147-158

DeLong EF, Taylor LT, Marsh TL, Preston CM (1999) Visualization and enumeration of marine planktonic archaea and bacteria by using polyribonucleotide probes and fluorescent in situ hybridization. Appl Environ Microbiol 65:5554-5563

- Ewart CS, Meyers MK, Wallner ER, McGillicuddy DJ, Carlson CA (2008) Microbial dynamics in cyclonic and anticyclonic mode-water eddies in the northwestern Sargasso Sea. Deep-Sea Res II 55:1334-1347

Ferrari GM, Dowell MD (1998) CDOM absorption characteristics with relation to fluorescence and salinity in coastal areas of the southern Baltic Sea. Estuar Coast Shelf Sci 47:91-105

Garcia HE, Locarnini RA, Boyer TP, Antonoy JI (2006) World ocean atlas 2005, Vol 3. Dissolved oxygen, apparent oxygen utilization, and oxygen saturation. In: Levitus S (ed) NOAA Atlas NESDIS 63. US Government Printing Office, Washington DC, p 342
Heissenberger A, Leppard GG, Herndl GJ (1996) Relationship between the intracellular integrity and the morphology of the capsular envelope in attached and free-living marine bacteria. Appl Environ Microbiol 62:4521-4528

- Herfort L, Schouten S, Abbas B, Veldhuis MJW and others (2007) Variations in spatial and temporal distribution of Archaea in the North Sea in relation to environmental variables. FEMS Microbiol Ecol 62:242-257

> Herndl GJ, Reinthaler T, Teira E, van Aken H, Veth C, Pernthaler A, Pernthaler J (2005) Contribution of Archaea to total prokaryotic production in the deep Atlantic Ocean. Appl Environ Microbiol 71:2303-2309

> Hu J, Kawamura H, Hong H, Qi Y (2000) A review on the currents in the South China Sea: seasonal circulation, South China Sea warm current and Kuroshio intrusion. J Oceanogr 56:607-624

- Hubberten U, Lara RJ, Kattner G (1994) Amino acid composition of seawater and dissolved humic substances in the Greenland Sea. Mar Chem 45:121-128

$>$ Hwang C, Chen SA (2000) Circulations and eddies over the South China Sea derived from TOPEX/Poseidon altimetry. J Geophys Res 105:23943-23966

Karner MB, DeLong EF, Karl DM (2001) Archaeal dominance in the mesopelagic zone of the Pacific Ocean. Nature 437:543-546

Kirchman DL, Elifantz H, Dittel AI, Malmstrom RR, Cottrell MT (2007) Standing stocks and activity of Archaea and Bacteria in the western Arctic Ocean. Limnol Oceanogr 52:495-507

Könneke M, Bernhard AE, de la Torre JR, Walker CB, Waterbury JB, Stahl DA (2005) Isolation of an autotrophic ammonia-oxidizing marine archaeon. Nature 437: 543-546

Lam P, Jensen MM, Lavik G, McGinnis DF and others (2007) Linking crenarchaeal and bacterial nitrification to anammox in the Black Sea. Proc Natl Acad Sci USA 104: 7104-7109

> Liu KK, Chao SY, Shaw PT, Gong GC, Chen CC, Tang TY (2002) Monsoon-forced chlorophyll distribution and primary production in the South China Sea: observations and a numerical study. Deep-Sea Res I 49:1387-1412

Lytle CR, Perdue EM (1981) Free, proteinaceous, and humicbound amino acids in river water containing high concentration of aquatic humus. Environ Sci Technol 15:224-228

- McGillicuddy DJ, Anderson LA, Bates NR, Bibby T and others (2007) Eddy/wind interactions stimulate extraordinary mid-ocean plankton blooms. Science 316:1021-1026

McKnight DM, Aiken GR (1998) Sources and age of aquatic humus. In: Hessen DO, Tranvik LJ (eds) Aquatic humic substances. Springer, p 9-39

Nagata T, Meon B, Kirchman DL (2003) Microbial degradation of peptidoglycan in seawater. Limnol Oceanogr 48: $745-754$

Obernosterer I, Herndl GJ (2000) Differences in the optical and biological reactivity of the humic and nonhumic dissolved organic carbon component in two contrasting coastal marine environments. Limnol Oceanogr 45: $1120-1129$

Ouverney CC, Fuhrman JA (2000) Marine planktonic Archaea take up amino acids. Appl Environ Microbiol 66: 4829-4833

Pai SC, Yang CC, Riley JP (1990) Effects of acidity and molybdate concentration on the kinetics of the formation of the phosphoantimonylmolybdenum blue complex. Anal Chim Acta 229:115-120

Pérez MT, Pausz C, Herndl GJ (2003) Major shift in bacterioplankton utilization of enantiomeric amino acids between 
surface waters and the ocean's interior. Limnol Oceanogr 48:755-763

Stoica E, Herndl GJ (2007) Contribution of Crenarchaeota and Euryarchaeota to the prokaryotic plankton in the coastal northwestern Black Sea. J Plankton Res 29: 699-706

Teira E, Reinthaler T, Pernthaler A, Pernthaler J, Herndl GJ (2004) Combining catalyzed reporter deposition-fluorescence in situ hybridization and microautoradiography to detect substrate utilization by Bacteria and Archaea in the deep ocean. Appl Environ Microbiol 70:4411-4414

Teira E, van Aken H, Veth C, Herndl GJ (2006a) Archaeal uptake of enantiomeric amino acids in meso- and bathypelagic waters of the North Atlantic. Limnol Oceanogr 51:60-69

Teira E, Lebaron P, van Aken H, Herndl GJ (2006b) Distribu-

Editorial responsibility: Craig Carlson,

Santa Barbara, California, USA tion and activity of Bacteria and Archaea in the deep water masses of the North Atlantic. Limnol Oceanogr 51: 2131-2144

Varela MM, van Aken HM, Sintes E, Herndl GJ (2008) Latitudinal trends of Crenarchaeota and Bacteria in the mesoand bathypelagic water masses of the Eastern North Atlantic. Environ Microbiol 10:110-124

Wang G, Su J, Chu PC (2003) Mesoscale eddies in the South China Sea observed with altimeter data. Geophys Res Lett 30:2121, doi:2110.1029/2003GL018532

- Wuchter C, Abbas B, Coolen MJL, Herfort L and others (2006) Archaeal nitrification in the ocean. Proc Natl Acad Sci USA 103:12317-12322

Yamashita Y, Tanoue E (2008) Production of bio-refractory fluorescent dissolved organic matter in the ocean interior. Nature Geosci 1:579-582

Submitted: November 25, 2008; Accepted: May 12, 2009 Proofs received from author(s): July 2, 2009 